Universidad de Lima

Facultad de Comunicación

Carrera de Comunicación

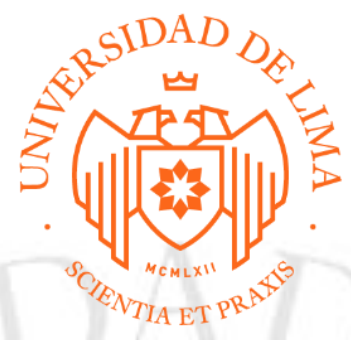

SCRIPT'S SPOT

\title{
UNA SERIE DE VIDEOS WEB PARA CONOCER TODO ACERCA DE ESCRIBIR GUIONES
}

Trabajo de Suficiencia Profesional para optar el Título Profesional de Licenciado en Comunicación

\section{Carlos Alberto Lopez Ezaine}

Código 20141954

\section{Asesor}

Giancarlo Cappello Flores

$$
\text { Lima - Perú }
$$

Febrero de 2020 


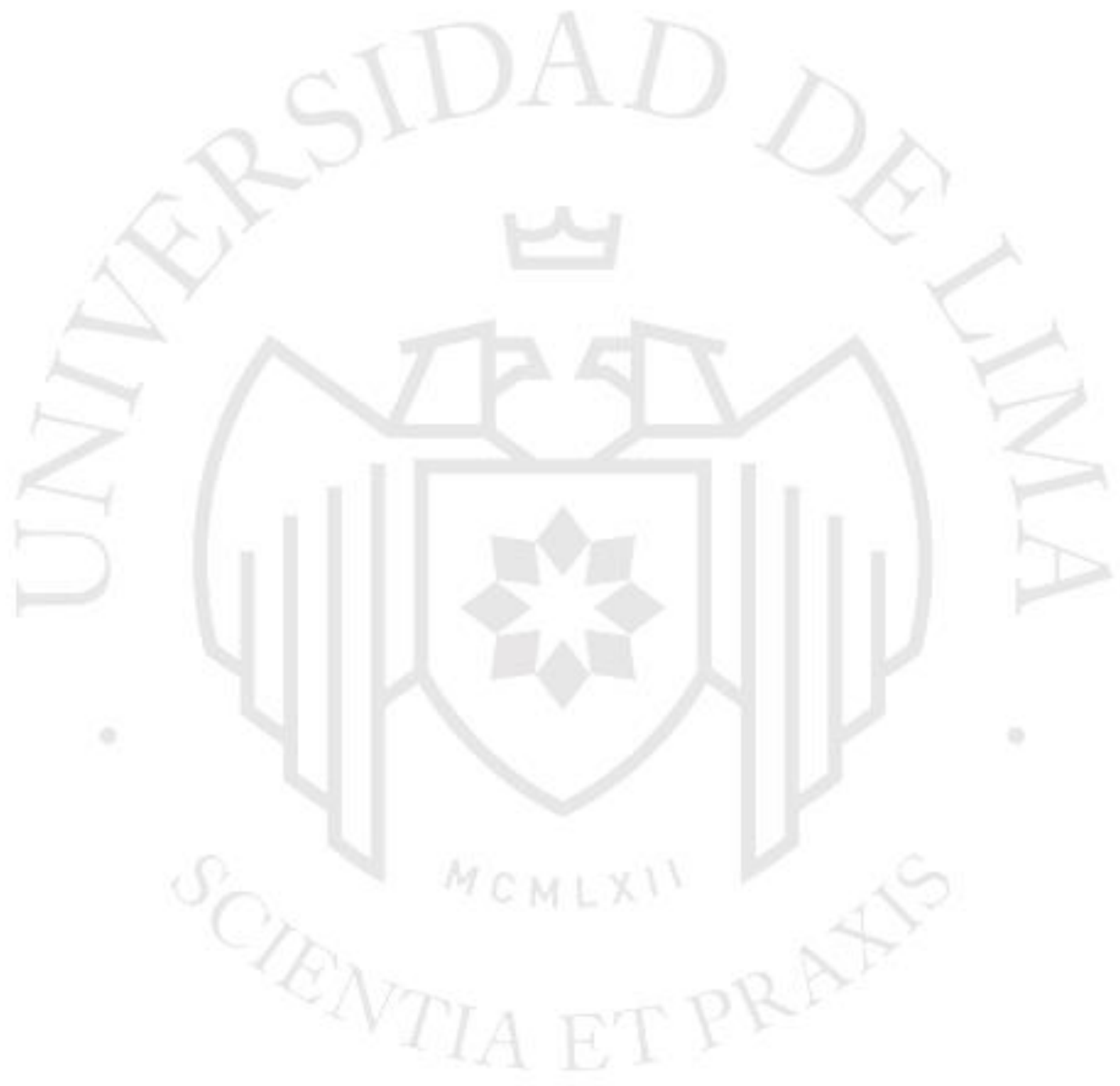




\section{SCRIPT'S SPOT}

\section{UNA SERIE DE VIDEOS WEB PARA CONOCER}

TODO ACERCA DE ESCRIBIR GUIONES 


\section{ÍNDICE}

\section{DIRECCIÓN WEB DE LAS PIEZAS Y PRODUCCIONES DE}

COMUNICACIÓN DEL TRABAJO ....................................5 pág.

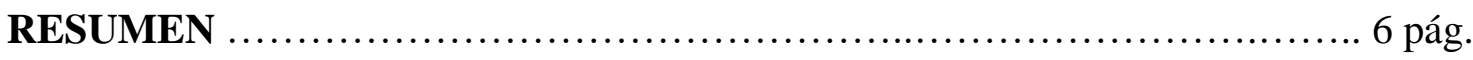

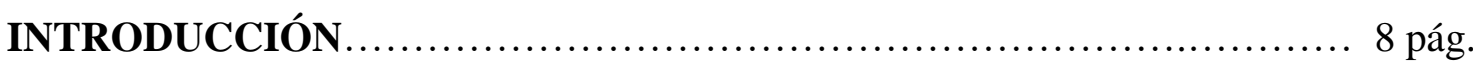

1. ANTECEDENTES DEL TRABAJO ................................

1.1 Conceptos básicos............................................11 pág.

1.2 Referentes............................................... 14 pág.

1.3 Perfil de públicos objetivos.......................................15 pág.

2. REALIZACIÓN Y SUSTENTACIÓN......................................18 pág.

2.1 Realización.......................................................18 pág.

2.2 Sustentación.................................................. 25 pág.

3. PLAN DE DIFUSIÓN Y MANTENIMIENTO ...........................27 pág.

3.1 Estrategia para la publicación del primer capítulo....................29 pág.

3.2 Flujo de trabajo ............................................30 pág.

3.2.1 Etapa pre-publicación..........................................30 pág.

3.2.2 Publicación del video........................................... pág.

3.2.3 Etapa post-publicación.......................................32 pág.

3.3 Parrilla de contenidos ...........................................35 pág.

3.4 Viaje del usuario..............................................43 pág.

4. PRÓXIMOS CAPÍTULOS DE LA SERIE ...............................45 pág.

5. COTIZACIÓN Y MONETIZACIÓN DEL PROYECTO.................. 47 pág.

5.1 Supuestos..................................................47 pág.

5.2 Presupuestos................................................48 pág.

6. LOGROS Y RESULTADOS .........................................51 pág.

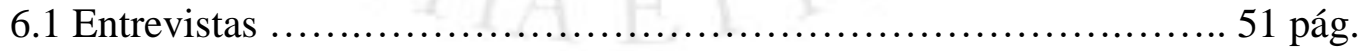

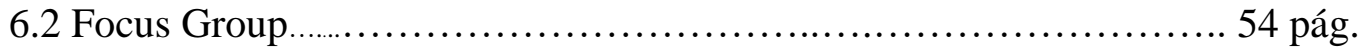

6.3 Conclusiones............................................... 55 pág.

6.3.1 Con respecto al capítulo piloto.............................. 55 pág.

6.3.2 Con respecto a futuros capítulos............................ 56 pág.

6.3.3 Con respecto al proyecto................................. 57 pág.

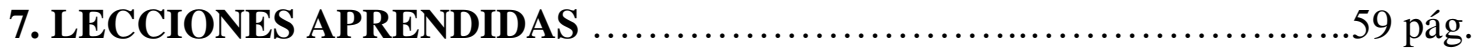

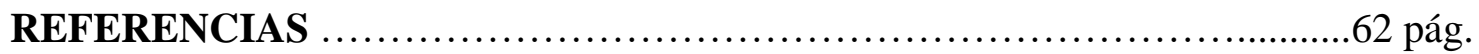


Dirección web de las piezas y producciones de comunicación del trabajo

https://drive.google.com/file/d/1DtErYI5gLtt9vfFB0CZzYyrl4oCx-

$\underline{3 \mathrm{Xh} / \mathrm{view} \text { ? usp=sharing }}$ 


\section{RESUMEN EN ESPAÑOL}

“Script's Spot" es una serie de videos acerca de temáticas de guión, la cual se caracteriza por juntar los formatos de video didáctico y videoblog. Esto se debe a que los objetivos principales del proyecto son los de entretener y enseñar acerca de estas temáticas. Las enseñanzas de los videos son narrados por un personaje, quien acompaña el relato a lo largo de toda la serie y, con su personalidad, da un estilo amigable y divertido al video. Además, en la parte del videoblog, se narra los acontecimientos de la vida del personaje para generar empatía con el espectador y, que esto genere un vínculo más cercano entre el discurso y el espectador. "Script's Spot” será publicada por YouTube, en un canal con el mismo nombre de la serie.

Este proyecto surge de la importancia del guión en el proceso creativo y la alta demanda que temáticas como el guión y el cine están teniendo en diferentes plataformas, entre estas la de YouTube. Esta serie busca permitir un mejor entendimiento por parte de los espectadores hacia las temáticas de guión expuestas en los videos, esto se realiza de una manera divertida y amigable.

Palabras clave: guión, video didáctico, videoblog, cine, Copyright, Storytelling, YouTube.

\section{RESUMEN EN INGLÉS}

"Script's Spot" is a serie of videos about script's subjects, which it's characterized by the union of two formats such as the didactic video and the videoblog. This union is because of the main objectives of the project, which are the entertainment and the learning about script's subjects. The video is narrated by a character, who is present in all the episodes and, with his personality, give a friendly and funny style to the video. Also, in the videoblog's part, it narrates the character's life to create empathy with the viewer and, it try to generate a closer relation between the speech and the viewer. "Script's Spot" will be publish in YouTube, in a channel with the same name as the serie of videos.

This project comes from the importance of the script in the creative process, and also because of the great demand of script and cinema's subjects are having in different 
platforms such as YouTube. This serie try to give a better understanding to the viewers about the script's subjects that are mentioned in the videos, this it's done in a funny and friendly way.

Keywords: Script, Didactic video, videoblog, Cinema, Copyright, Storytelling, YouTube.

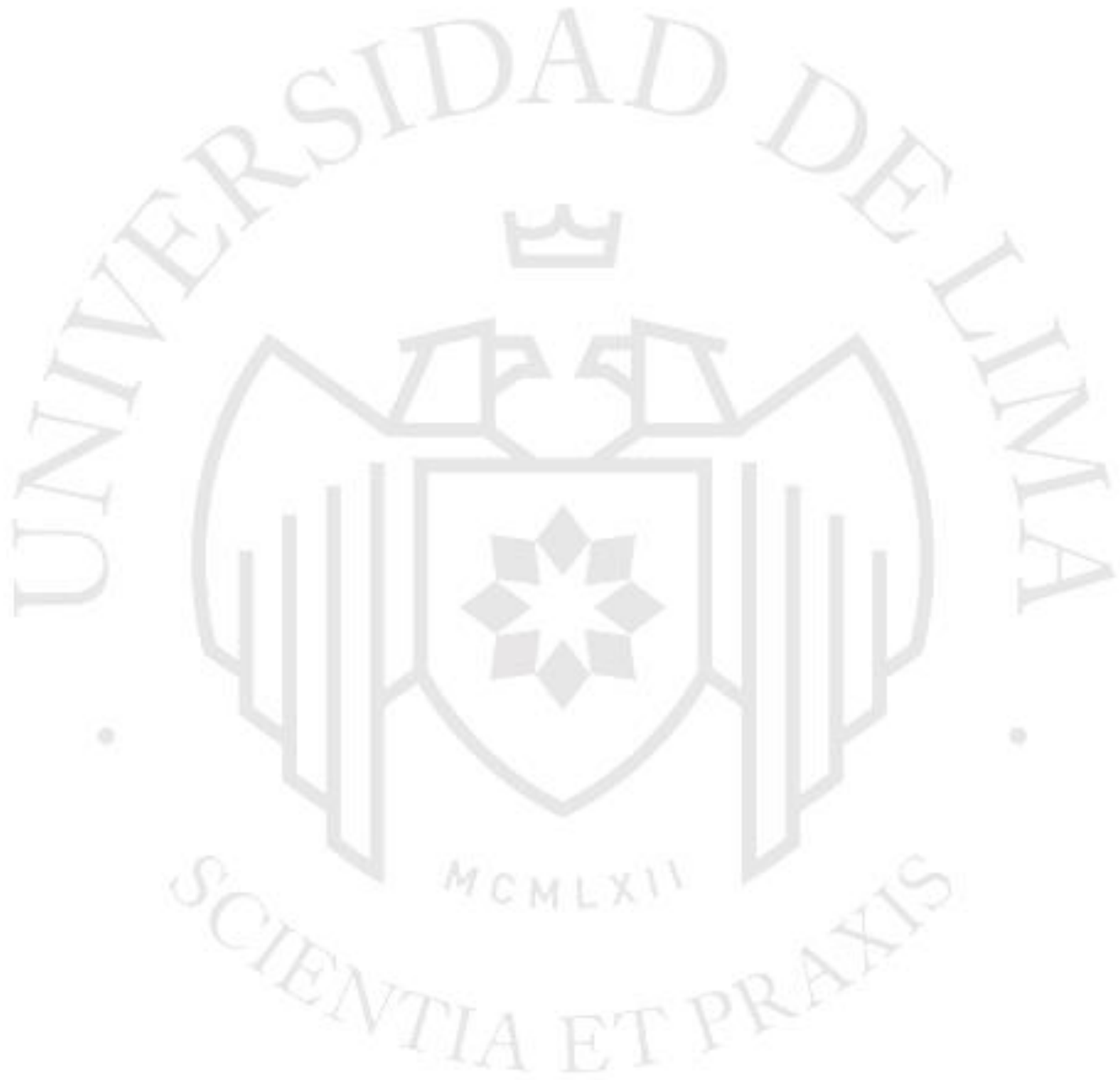




\section{INTRODUCCIÓN}

El presente proyecto se trata acerca de una serie de videos acerca de temáticas de guión, estos videos combinan los formatos de videoblog y del video didáctico, con el fin de entretener e informar al mismo tiempo. Esto quiere decir que este proyecto tiene dos objetivos generales, que son los de enseñar acerca de temáticas de guión, y la de entretener por medio del discurso audiovisual que se traducirá en una serie de videos que juntarán los formatos del videoblog y del video didáctico.

El primer objetivo de enseñanza se realizará mediante la explicación de ciertos conceptos de guión que pueden mejorar la estructura narrativa de una historia; esto se realizará por medio de palabras claves puestas en el video para que, de manera resaltante, el espectador pueda entender la importancia de un concepto o alguna función, esto sirve para los propósitos del discurso. También, como se mencionó, el objetivo de enseñanza se logrará por medio del resaltar de las funciones específicas de estos conceptos de guión en la historia, pues se explicará cómo el concepto explicado puede ayudar a mejorar la historia del espectador. Por último, este primer objetivo se apoyará en la ejemplificación de estos conceptos en ciertas películas, tanto de manera positiva como negativa, es decir, películas que usaron bien el concepto y las que no; esta manera tiene como fin que el espectador pueda relacionar mejor los conceptos y entender, de una manera más óptima, la explicación de cada concepto o función.

El segundo objetivo de entretenimiento se realizará mediante la creación de personaje excéntrico y dinámico que acompaña la transmisión de conocimientos de temáticas de guión, esto se utilizará como recurso para enganchar al público con el discurso y buscar generar simpatía y/o risa para crear interés en el producto. Asimismo, se hará uso de recursos como música o efectos que dan rasgos cómicos al discurso, esto ayudará para reforzar el entretenimiento que se le da al espectador y también tiene como función darle una personalidad al personaje mediante este recurso. Además, en la parte de videoblog se presentará la creación de una historia previa para el personaje para que este pueda empatizar con el espectador, esto contribuirá en la generación de enganche con la historia y el personaje y, por consiguiente, con el contenido del vídeo.

Asimismo, es importante recordar que este producto se moverá por YouTube, pero también por otras dos plataformas como son: Instagram y Twitter, las actividades que se realizarán en esta plataformas se explicarán con más detalle en el Capítulo III de "Plan de Difusión y Mantenimiento", pero es importante mencionar que en esta primera etapa del proyecto se tiene como objetivo secundario: Crear una comunidad fiel de seguidores que puedan ser consumidores de este y de otros tipos de contenido relacionados a la temática de guión y del cine, esto se logrará 
por medio de las actividades que se realicen tanto en los capítulos publicados en YouTube como en las demás redes sociales.

También hay que destacar al personaje, cuyo nombre es "Sr. Script", un guionista de 25 años que vive con sus padres y que tiene un trabajo que odia. Como ya se mencionó, el personaje buscará apelar a la emoción del público por medio de su historia y su personalidad. Este proyecto narrará situaciones que le van pasando al narrador en cada capítulo, sin embargo, no será necesario ver cada capítulo para entender la situación que está viviendo o entender la enseñanza del capítulo.

Es importante recordar que el producto de muestra en este Trabajo de Licenciatura consta de un video piloto en el cual se presenta el estilo, el tono y, la propuesta visual y acústica que tendrán los capítulos de la serie. También se determinó, a grandes rasgos, las vivencias del personaje a lo largo de los capítulos y su relación con el contenido de la parte didáctica, este aspecto se encuentra más detallado en el Capítulo 4 "Próximos capítulos de la serie".

Por otro lado, en esta serie se va a desarrollar, en la parte didáctica; temáticas de guión que pueden servir de utilidad para los diversos públicos objetivos planteados en el Capítulo I "Antecedentes del trabajo" del presente proyecto. También es importante resaltar que la primera etapa del proyecto consta de 7 capítulos, que servirán de referencia para la siguiente etapa del proyecto y para tomar decisiones con respecto al rumbo del este.

Para este proyecto, se eligió la plataforma de YouTube como medio por el cual difundir la serie de videos acerca de temáticas de guión, se eligió este ya que tiene un mayor alcance hacia diferentes públicos, por su popularidad como red social y por la posibilidad de buscar videos mediantes etiquetas específicas que pueden ayudar a segmentar el contenido del canal en esta plataforma. En cuanto al nombre de la serie, y también del canal, se decidió por "Script's Spot" ya que hace alusión al "rincón" o "lugar" que un guionista tiene al crear sus historias y, también refiere al reconocimiento reducido que los espectadores de las películas o series les dan a los guionistas, favoreciendo más a los actores o al director que a los escritores.

Como justificación del proyecto, se debe resaltar que estos tipos de contenidos están generando alta demanda en YouTube. Los contenidos relacionados al cine tienen grandes referentes con bastantes seguidores fieles que consumen este tipo de contenido, por ejemplo está el caso del canal "Te lo resumo" con 3.98 Millones de suscriptores o Lesson from Screenplay con 1.16 Millones de suscriptores, También, está el caso de NerdWriter1 con 2.76 Millones de seguidores, es decir, hay un público que gusta de este tipo de contenido que es didáctico, interactivo y que habla de cine, en general. Además hay una gran importancia en enseñar acerca del guión como 
dice Garrido "La estructuración del guión y el montaje son los dos momentos fundamentales que articulan esta propuesta artística." (2015), es decir, la enseñanza acerca de temáticas de guión se puede aplicar a diversos ámbitos que involucren una propuesta artística; y es una pieza fundamental en el proceso creativo.

Finalmente, se puede afirmar que con estos vídeos, la intención es enseñar al espectador conceptos simples, pero muy importantes, en la creación de una historia y en el desarrollo del guión; además se busca brindarlo de una manera ligera y divertida para que el espectador encuentre un contenido amigable e interesante, es decir, que también pueda ver en sus ratos de ocio. Así, este trabajo permitirá un mejor entendimiento por parte de los espectadores hacia las temáticas de guión expuestas en los videos, y permitirá que la transmisión de conocimientos hacia el espectador sea de una manera afable, con la ayuda del personaje narrador. Cabe resaltar que si bien el contexto en el que se desarrolla el proyecto es en Perú, este contenido puede servir para públicos de otras partes del mundo, ya que uno de los objetivos de este trabajo es buscar enseñar sobre temáticas de guión a quien lo necesite o requiera. 


\section{ANTECEDENTES DEL TRABAJO}

En este capítulo se explicarán tres puntos importantes del proyecto: los conceptos básicos a entender acerca del trabajo, los principales referentes del medio sobre los cuales se ha basado el presente proyecto y el perfil de los públicos objetivos a los cuales va dirigido el producto final.

\subsection{Conceptos básicos}

En los últimos años, se ha ido desarrollando un crecimiento considerable en el consumo por parte del usuario en la plataforma YouTube. Esta plataforma fue elegida para el proyecto debido a que ayudará a alcanzar un rango mayor, en cuanto al público, y facilitará la búsqueda de los vídeos acerca de temáticas de guión por medio de "etiquetas" que agrupan los diferentes tipos de contenidos en la plataforma. Las etiquetas que se usarán serán unas como "Cine", "Guión”, "Películas" entre otras.

En esta plataforma, han surgido creadores de contenido denominados "youtubers", los cuales se expresan a través de diferentes tipos de formato, y en diferentes estilos y tonos. Tomando esto como precedente, también se puede encontrar a los videos didácticos entre estos diferentes tipos de formatos. Entendemos a los video didácticos como "aquel vídeo que ha sido diseñado y producido para transmitir unos contenidos, habilidades o actividades" (Cabero, 1989, citado por Ramos y Flores). Este tipo formato será empleado en este proyecto.

Es importante mencionar que hay aspectos del contenido como los derechos de autor o el Copyright, estos se refieren al "Derecho exclusivo que el Estado confiere al creador de una obra intelectual como medio de protección de su obra frente a terceros" (Labastida \& Iglesias, 2006), esto puede ser perjudicial para algunos capítulos del canal, ya que pueden tener problemas por infringir esta norma que se aplica en la plataforma de YouTube. Una alternativa a esto es el denominado "Fair Use", que consiste en poder utilizar contenido con derechos de autor con la finalidad de enseñar o analizar algún fragmento o elemento de la obra de un tercero. Normalmente, los videos que utilizan este recurso no monetizan, pero en la página web de "YouTube About" se menciona “...es posible obtener ingresos con un vídeo y sacar provecho de la defensa del uso legítimo" (YouTube, S.F); lo cual abre una posibilidad que con esta serie se puedan monetizar algunos capítulos, sin embargo, el ingreso monetario no es un elemento vital en esta primera etapa del proyecto, sino más bien lo es la creación de una comunidad de fieles seguidores al contenido que se realiza y, a nuevos posibles tipos de contenido que se puedan incluir en el proyecto en un futuro. También, es importante precisar que los videos que son aptos para monetizar son de una extensión de 10 minutos o más. 
Continuando con la temática del Copyright, hay dos maneras en que la plataforma puede perjudicar a un creador de contenido con los derechos de autor, uno es a través del Content ID, que es un sistema que tiene una gran base de datos con material audiovisual. "Los vídeos subidos a YouTube se analizan y cotejan con una base de datos de archivos que nos han enviado los propietarios de contenido." (YouTube, S.F.); en donde el Content ID identifica un extracto de un video con la base de datos que posee y, si encuentra similitudes, existe la posibilidad de que YouTube censure el video. Mientras que la otra manera, es una búsqueda y reclamo manual de personas que son contratadas por los creadores de contenido o por grandes productoras; esto en la búsqueda de monetizar el video donde aparecen los extractos de contenido con copyright o de censurarlos.

Con estos obstáculos, se plantea utilizar recursos como cambiar la orientación de los fragmentos de videos, poner elementos que modifiquen la imagen original, evitar poner nombre de películas en los títulos de los capítulos para que sean detectadas, entre otras cosas; pues, si bien un objetivo de este proyecto apunta más a la creación de una comunidad de fieles seguidores del contenido del proyecto que a una monetización inmediata; la posibilidad para monetizar con futuros capítulos está abierta; por lo cual se empleará un sistema de un canal secundario, el cual se explica más detalladamente en el capítulo III de "Plan de Difusión y Mantenimiento".

De igual manera, una breve explicación es que consistirá en tener un canal secundario en donde se suban los videos y revisar si YouTube detecta algún clip de contenido con copyright y, luego cambiarlo en el programa de edición, y volverlo a subir al canal secundario hasta que ya no logre detectar algún contenido con copyright en el video; en ese momento, recién se subiría el video al canal principal. Este método lo utiliza el youtuber "Jaime Altozano", quien genera contenido en YouTube analizando bandas sonoras de películas y música con Copyright, por lo que tiene experiencia lidiando con problemas acerca de los derechos de autor. Asimismo, se trabajará en futuros capítulos con la plataforma de "Epidemic Sound", la cual permite el uso de música con Copyright a cambio de una suscripción mensual, y así se evita problemas en temas de desmonetización o bloqueo de videos por derechos de autor, en cuestión de música que pueda ser utilizada en el vídeo.

Asimismo, a medida que se fue avanzando el trabajo, se incorporó una sección de videoblog, en la cual se narra la vida de un personaje ficticio que locuta el video. También, es importante mencionar al canal "Te lo resumo" como referente en el estilo y el tono en los que se expresa el personaje, ya que se considera que este es simpático y que puede encajar de la mejor manera con los gustos del público objetivo. Esta parte se realiza con el fin de cumplir el objetivo de entretenimiento y empatizar con el espectador. Arias, en su artículo científico "Evolución de la 
comunicación audiovisual: de la televisión clásica al videoblog”, hace una comparación entre el blog y el videoblog "Además, mientras que los textos de los blogs son casi siempre opinativos, el vídeo es una forma de comunicación testimonial y expresiva." (2006); esta cita demuestra que el videoblog puede ser usado como un recurso herramienta de testimonio, como bien se usa en este proyecto.

Ahondando más en esta sección del videoblog, para el estilo de esta parte, se utiliza una voz en off mientras se dramatiza lo que está contando el narrador. En la plataforma, se puede encontrar como referente a "Te lo Resumo" que utiliza esta dramatización en los vídeos de su sección "Sin Fumar" con el mismo fin de empatizar con el espectador. Este contenido es complementario a sus videos de resúmenes y ayuda a generar empatía con el narrador al mostrarnos cómo piensa con respectos a ciertas temáticas, un ejemplo claro de esto es el episodio de "Sin Fumar | Crítica a Avengers Infinity War (Hasta las manos de spoilers)" en donde el narrador muestra tomas de su vida diaria en donde reflexiona sobre por qué le gustó tanto la película "Infinity War" y, también, qué cosas no le gustaron tanto. (Te lo resumo, 2018)

Además, se planteó el elemento del storytelling (herramienta que se introdujo producto de la combinación de los dos formatos antes mencionados) el cual "hace referencia a combinar el arte de contar cuentos con una variedad de elementos digitales multimedia como imágenes, audio, vídeo y música para presentar la información de un tema específico" (como se cita en Rosales y Roig-Villa, 2017); así este recurso ayuda en la búsqueda por lograr ambos objetivos, tanto el de entretenimiento como el de enseñanza, ya que ayuda a presentar información acerca de un tema específico de una manera que combina con la ficción en el ambiente digital multimedia.

También se añadieron elementos de otros referentes como el de la voz "interior", es decir, que usa un filtro que hace alusión a la voz interior del narrador que está locutando, este recurso es utilizado por el canal "The Top Comics", lo utiliza, principalmente, para hacer aclaraciones sobre ciertos temas, realizar algún comentario sarcástico o chiste adicional.

Finalmente, un elemento que se añadió en el proceso de post producción, el cual es importante mencionar, son los memes que en este proyecto se utilizan con el recurso del video; aunque normalmente se utilice más frecuentemente con fotos o imágenes de internet, con el fin de generar gracia y simpatía en el espectador. 


\subsection{Referentes}

\section{Temática}

Como ya se mencionó y para profundizar en los referentes puestos en el punto anterior, tenemos referentes a nivel de temática como "Lesson From Screenplay" o "Just Write", los cuales enseñan acerca de temática de guión con fines didácticos y poniendo ejemplos de películas o series como referentes para que el público pueda entender mejor el objetivo de su discurso. Pero, y como rasgo diferencial, se puede decir que estos canales no utilizan la herramienta de storytelling en sus videos por medio de un personaje, lo cual da a este proyecto una gran ventaja en el aspecto empático y de entretenimiento, pues "Script's Spot" presenta a un personaje que presenta problemas comunes y, con el cual, es fácil relacionarse.

\section{Formato}

También, en el aspecto de formato, tenemos canales como "StudioBinder" o "Alvinsch" en donde, la mayoría de sus videos, tienen fines didácticos o de buscar iniciar una conversación con respecto al tema del cual están hablando. Si bien "Alvinsch" hace más hincapié en temáticas referidas a la música, sus videos buscan informar acerca de diferentes conceptos del mundo musical, y esto lo realiza a través de ejemplos de los cuales él, desde su subjetividad, considera "buenos" o "malos", para luego dar sus argumentos acerca del por qué de este parecer. Por otro lado, los videos de "StudioBinder" tienen un fin didáctico, en los cuales explica un concepto y cómo aplicarlo bien en un cortometraje o largometraje; asimismo, pone ejemplos de películas que él considera que utilizan bien el recurso explicado.

Estilo

En el aspecto de estilo, como referentes tenemos a "Alvinsch" y a "DayoScript" que usan bastante el sarcasmo y el humor como recurso para explicar las temáticas de las cuales hablan en sus videos. Esto también lo logran analizando, desde su subjetividad, ciertas películas, series o canciones sobre las cuales emiten un juicio y la ponen como ejemplo positivo o negativo para demostrar su punto.

También están los referentes de "Te lo resumo" y de "The Top Comics" de los cuales se agarran elementos técnicos y de estilo visual. En el caso de "Te lo resumo", este usa códigos visuales y auditivos para interactuar con su público y recibe un feedback bastante abundante; este recurso se usa en este proyecto, aunque en diferente forma y presentación. En el caso de "The Top Comics", principalmente, se hereda el uso de la pantalla negra para los pensamientos "internos" y "sarcásticos" del personaje; y estilo de humor que tiene en secciones como "Cosas que no tienen sentido de..." 


\section{Diferenciación de los referentes}

Si bien se toman diferentes aspectos de estos referentes, "Script's Spot" busca diferenciarse por medio de la unión del formato de video didáctico y del videoblog para la creación de una serie de videos que usen la herramienta de storytelling como enganche y los conocimientos acerca de temáticas de guión para cumplir la función de enseñar. Los casos más similares en esta relación, serían los de "DayoScript" y "Alvinsch", los cuales tienen similitudes en el estilo de locución del proyecto.

Sin embargo, en estos casos, "Script's Spot" se diferencia por su temática y por la profundidad en la que se ahonda en esta, así buscan expresarse sobre temas de guión que pueden parecer "básicos", pero que el video te invita a reflexionar sobre su importancia. Es decir, al mezclar estos dos formatos, la propuesta se vuelve diferencial con respecto a varios canales y/o proyectos que están en el ámbito de YouTube y que pueden llegar a hablar sobre los mismos temas, pero de una manera diferente.

En el caso de Perú, específicamente, en cuanto a análisis de guión, el contexto no es muy amplio. Existen canales como "Cinesmero", "Los Cinéfilos" y "Andrés Barr", los cuales hablan sobre temáticas del cine en general, sin ser enfáticos en algún área del cine en específico. "Los Cinéfilos" utilizan el recurso de la dramatización para algunos sketches que realizan, pero lo presentan de una manera diferente a la de "Script's Spot", además su canal no produce contenido desde hace 3 años, por lo cual se les considera "inactivos". En los otros dos casos, sus videos si bien son con fines didácticos hasta cierto punto; se presentan más como "video críticas" o "análisis de películas" en específico, sin tocar un tema en específico.

En conclusión, podemos decir que "Script's Spot" tiene elementos similares de algunos referentes importantes internacionales, pero que por la fusión de los dos formatos que posee, este proyecto tiene un ángulo diferencial importante, y del cual se puede sacar provecho para la creación de diferentes tipos de contenido y para fidelización del público; y en Perú, todavía más, ya que se presenta en un contexto donde falta este tipo de contenido acerca de este tema en específico.

\subsection{Perfil de públicos objetivos}

En cuestión al público objetivo al cual va dirigido este proyecto, en una primera instancia, este contenido está dirigido a un público amante del cine y de las series, que busque contenido de análisis referidos a películas o series. Este es uno de los públicos objetivos más amplios, y por el cual se genera una mayor difusión del contenido realizado. Entre las principales características de este público están el visionado constante de películas, ya sean de culto o no, y un carácter analítico acerca del contenido que ven, así buscando contenido que refuerce su análisis propio o 
que les de material nuevo que enriquezca su conocimiento. A su vez, también navegan por internet buscando contenido de entretenimiento en sus ratos de ocio como escape de la rutina.

Por otro lado, está el público que buscan conocimientos nuevos en cuanto al contenido narrativo de sus películas y series favoritas, estos se caracterizan por ser minuciosos al momento de ver una película y buscan explicaciones al gusto o disgusto que una serie o película les dejó; son más analíticos pues piensan, más específicamente, en términos de historia y personajes. También, se les puede considerar más perfeccionistas ya que se perturban o fascinan por algo que les llamó la atención e investigan acerca del tema. Igual que el primer grupo, disfrutan del contenido de entretenimiento en sus ratos libres.

Luego están los creadores de contenido audiovisual, en este caso guionistas o realizadores, que buscan nuevos contenidos para inspirarse en sus historias y maneras de hacerlas mejor o más interesantes. Este público es más creativo y aplicativo, pues piensan en soluciones novedosas a partir del contenido o consejo que se les ha dado, y lo aplican a sus propias historias para así tener un mejor producto final.

Finalmente, el público objetivo más específico son jóvenes de entre 20 a 23 años, que gusten del cine, y más específico de temáticas de guión para aplicarlas a sus cortometrajes, y próximamente a sus largometrajes. Este público es inexperto pero con muchas ansias de aprender, también es creativo, en menor medida, y aplicativo pues utilizan los conceptos dados en sus propias creaciones. Son personas activas en el sentido de la realización, pues los conocimientos que se les dé, no sólo serán aplicados al guión, sino también realizados y posteriormente editados.

Buyer Person:

Con el propósito de definir y ejemplificar mejor el espectador a quien va dirigido el producto, se ha planteado este "Buyer Person" que representa al público ideal que consumirían los videos:

Ricardo Rodríguez, 20 años

PERSONAL:

Estudiante. 4to ciclo de Universidad. Estudia Ciencias de la Comunicación y quiere hacer cortometrajes propios en un futuro no muy

\section{PENSAMIENTOS:}

Está interesado en los próximos estrenos en la cartelera del cine. Quiere realizar cortometrajes para catapultar su futura carrera, quiere hacer un cambio en el mercado del Cine Peruano, así evitando crear 


\begin{tabular}{|c|c|}
\hline $\begin{array}{l}\text { lejano. De momento, sólo ha grabado algunos } \\
\text { cortos para algún curso de la Universidad. }\end{array}$ & $\begin{array}{l}\text { historias facilistas o mediocres, desde su punto de } \\
\text { vista. }\end{array}$ \\
\hline $\begin{array}{l}\text { OCIO: } \\
\text { Suele ver bastantes películas y buscar videos } \\
\text { en YouTube que hablen sobre el cine o series. } \\
\text { Utiliza Twitter e Instagram, principalmente, en } \\
\text { sus ratos de ocio. Se rodea de gente que tiene } \\
\text { el mismo gusto por el cine y la intención de } \\
\text { hacer cortos propios. }\end{array}$ & $\begin{array}{l}\text { ESTILO DE VIDA: } \\
\text { Estudiante promedio, clase B, trata de ahorrar lo que } \\
\text { puede para sus cortometrajes. Siempre almuerza o } \\
\text { cena cerca o dentro de la Universidad para que le } \\
\text { sea más económico. Se mueve en transporte } \\
\text { público. }\end{array}$ \\
\hline
\end{tabular}

Cabe volver a resaltar que, este Buyer Person representa al "espectador ideal" del producto, la serie de videos puede llegar de igual manera a otros varios tipos de espectadores pertenecientes a los otros grupos ya mencionados en el acápite de "Perfil de públicos objetivo".

En síntesis, este primer capítulo nos describe la base conceptual para entender el entorno donde el proyecto se desarrolla, es decir, la plataforma en donde se va a publicar, los recursos que se usan para la serie y los públicos a los que va dirigido el proyecto. 


\section{REALIZACIÓN y SUSTENTACIÓN}

En este capítulo se explicará el proceso de realización paso a paso del proyecto y del producto que se realizó para este Trabajo de Licenciatura que fue, como ya se mencionó, un video piloto que traza el estilo, el tono y, la propuesta visual y acústica del proyecto. Esto se ilustrará con fotos en las fases más representativas del proyecto. Asimismo, en el apartado de sustentación se resaltan los puntos más importantes del proceso y, se hace énfasis en los argumentos teóricos y conceptuales sobre los cuales me he basado, para incluir esas partes o recursos del proceso en el proyecto final.

\subsection{Realización:}

Es importante recalcar que, en un inicio, el proyecto tenía pensado usar una locución neutra y con un estilo explicativo e imparcial. Además, "Script's Spot" inicialmente era un producto para la plataforma de YouTube de la productora de "Desvío Producciones" como parte de la diversificación de contenido de la productora. Con estos dos puntos en cuenta, lo primero que se realizó en el curso de "Trabajo Profesional II" fue el replanteamiento del estilo de presentación y locución de los videos, esto se realizó en búsqueda de generar una mayor simpatía con el espectador, y generar un "enganche" entre el usuario y el contenido, asó evitando que la persona, quien está viendo el video, lo siga viendo.

El nuevo estilo planteado consiste en la narración subjetiva de un personaje con un punto de vista radical acerca del mundo del cine, y más en concreto, sobre las temáticas de guión. También, este cambio se realizó debido al planteamiento del objetivo de entretenimiento, es decir, se busca alcanzar este objetivo por medio de este personaje excéntrico.

En un punto, el trato con "Desvío Producciones" se disolvió y se optó por desarrollar la serie de videos con temáticas de guión de manera independiente, por medio de un canal de YouTube como plataforma principal. Esto ayudó a tener más libertad creativa en el proceso y a acelerar ciertas fases de este. De igual manera, se decidió continuar en la plataforma de YouTube para tener el máximo alcance posible y desarrollar de la mejor manera posible el proyecto.

Para empezar este nuevo proceso creativo, se creó y definió bien al personaje. Se hizo un perfil para determinar sus expresiones, así como su forma de explicar los puntos a tratar en cada video. Esto implicó a responder las 7 preguntas del actor, recurso que usan los actores para formar de mejor manera a los personajes que interpretan, y realizar una pequeña fábula del personaje que narre su vida previa al inicio de la serie de los videos. 
Por motivo de este cambio, se hicieron pruebas de locuciones para ver cómo se expresaría el personaje, tomando como base el guión antiguo. En este proceso, se buscó encontrar el mejor estilo por medio de la improvisación, para tener el estilo más natural posible. Pero, luego de evaluar algunas opciones, se decidió que se redacte un guión más pautado y que sirva de base para practicar y encontrar el mejor estilo posible.

A consecuencia de esto, se tuvo que reescribir el guión previamente planteado (el que tenía la locución neutra e imparcial) para que este se ajuste al personaje. Este cambio incluyó: añadir bromas, tanto verbales como visuales; un cambio de cómo se explicaban los términos; asimismo, se buscaron y se pusieron como ejemplo algunas películas específicas que reforzaban el sentido cómico del discurso; por ejemplo varias películas de Adam Sandler; entre otras más.

Al tener un primer borrador del guión, se notó que el personaje podría no tener mucha empatía y enganche por el público, esto por el hecho de ser radical y brusco en sus opiniones. Por ese motivo, se añadió una parte videoblog, en donde se narra la historia del personaje para causar empatía con valores y actitudes con los cuales, popularmente, las personas se relacionan muy bien como, por ejemplo, "la lucha por alcanzar los sueños" o "el alzamiento del oprimido". Esta parte, permitió la implementación de la herramienta del storytelling dentro del proyecto, para así enganchar al espectador con los videos.

Teniendo esto en cuenta, se grabaron las nuevas pruebas de locución. En donde se realizaron más de 100 grabaciones de voz de varias partes del nuevo guión, cada una con varios tipos de entonación.

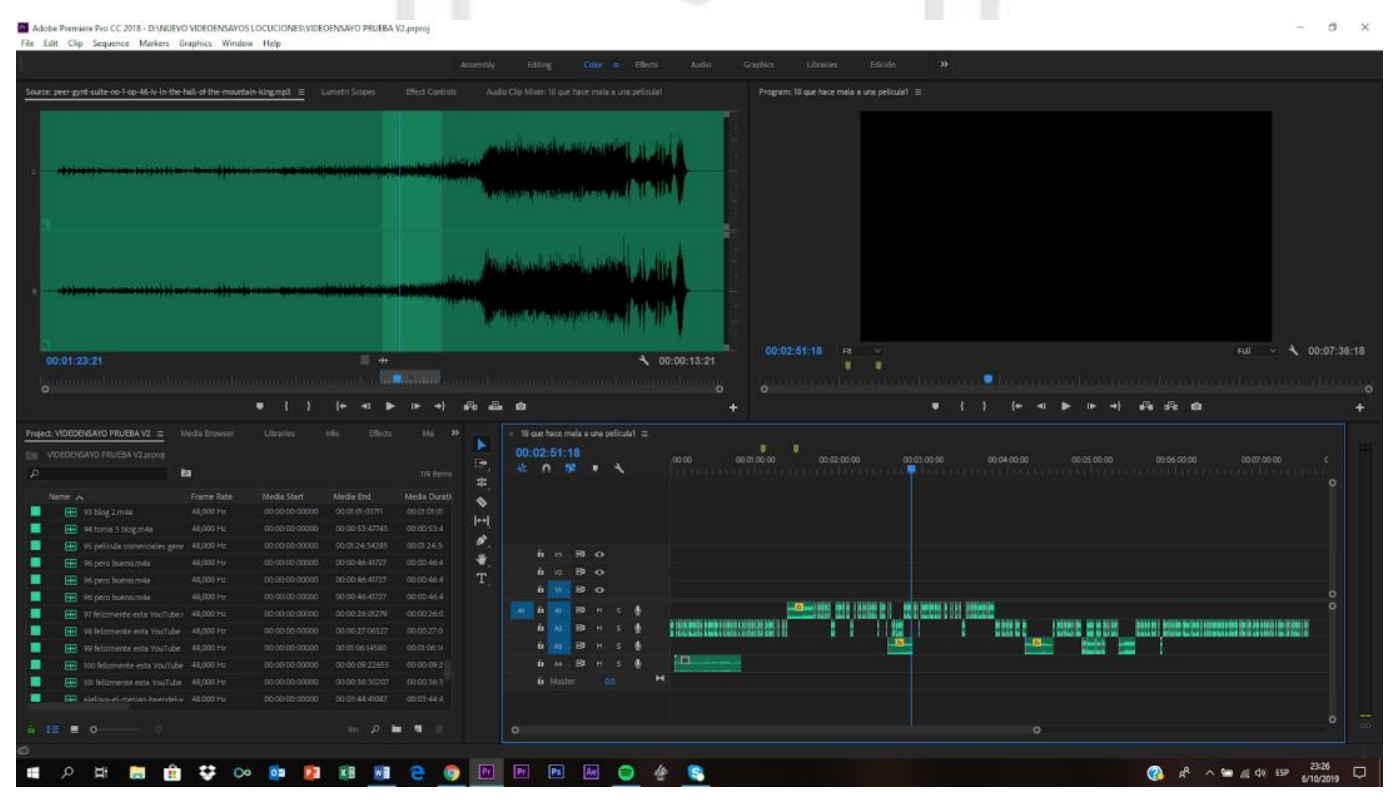


Después, se hizo una selección de cuál quedaba mejor según el momento del video (En este proceso, estaba incluido tanto la parte didáctica como la del videoblog.). Además de la grabación de voz, se incluyeron algunos efectos, audios de escenas que servían como ejemplo de algún tema; y música, en su mayoría canciones de música clásica, para así evitar problemas con el copyright; todo esto para reforzar el discurso planteado. Adicionalmente, a algunas partes de la locución se les puso un filtro que emulaba la "voz interior" del locutor, estas partes de la locución iba acompañado por una pantalla negra, para así representar el pensamiento interno del personaje narrador.

Luego de esto, se presentó el avance al profesor del curso para recibir retroalimentación sobre qué se podría mejorar acerca de la locución; este proceso también se llevó a cabo con personas próximas las cuales dieron su opinión sobre el audio y sus recomendaciones. Básicamente, sólo dieron algunas recomendaciones técnicas de sonido, pero en términos generales todo se encontraba bien con la locución y la calidad del audio. Finalmente, se hicieron los cambios respectivos y la locución quedó lista.

En el planteamiento visual del video, el trabajo se dividió en dos partes: la parte didáctica y la parte videoblog. Primero se trabajó la parte didáctica, la cual está compuesta por imágenes de películas que refuerzan el discurso que se está locutando, asimismo, se agregaron secuencias en las que se agregan textos que buscan emular a los "memes", para así generar simpatía en el espectador.

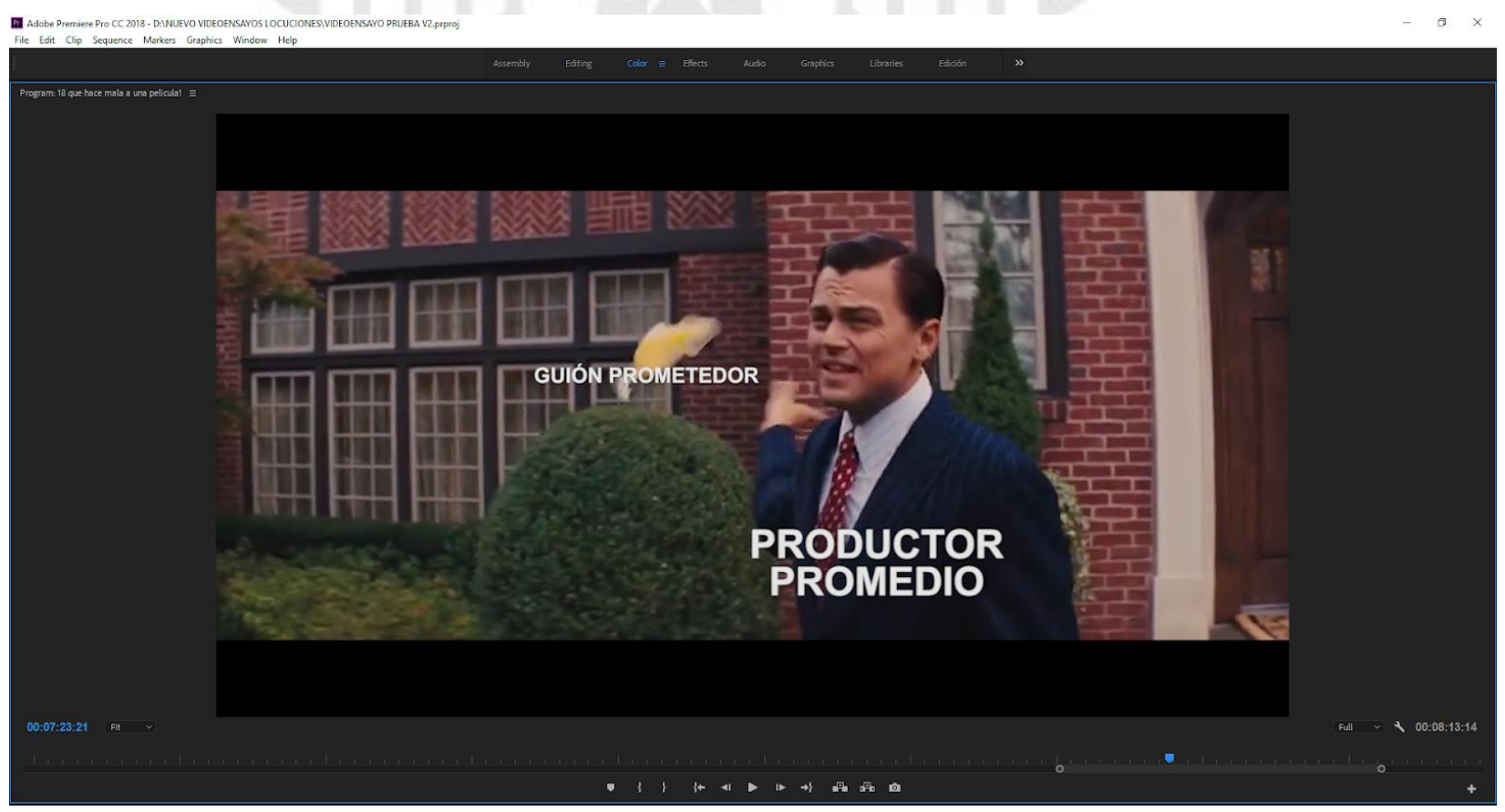


Además, se utilizó una secuencia especial en donde se hace especial énfasis a la figura de "Adam Sandler" con música clásica estruendosa con el fin de generar gracia en el espectador, así como para esclarecer el punto de vista del personaje con respecto a este personaje y al mundo del cine comercial, en general.

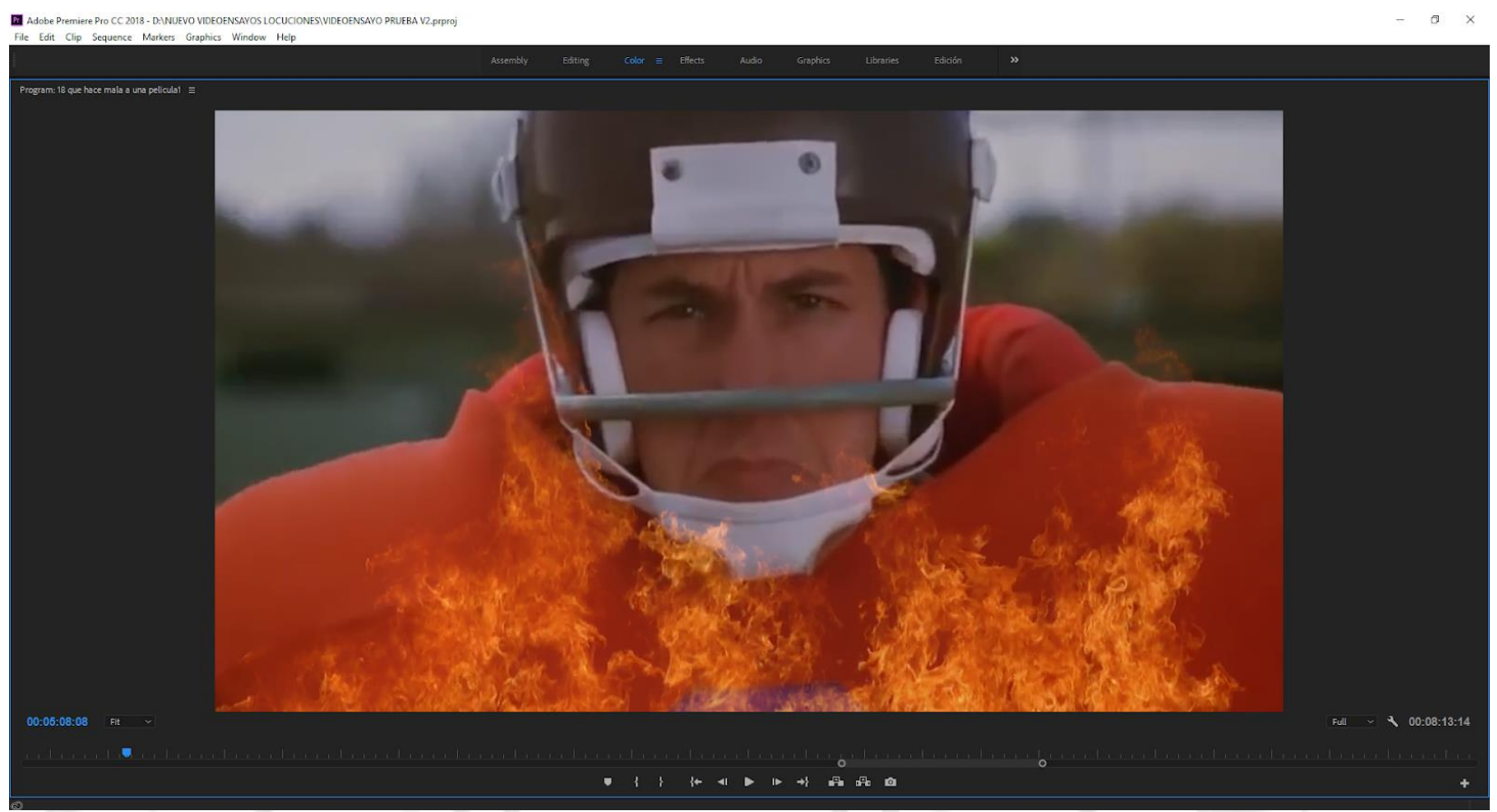

También se añadieron textos que resaltan el tema o el consejo que se está dando, para resaltar lo enseñado. Estos textos son acompañados por barras amarillas que refuerzan el énfasis en esas ideas y emulan a los "post it", que popularmente se usan para tomar notas acerca de algo importante.

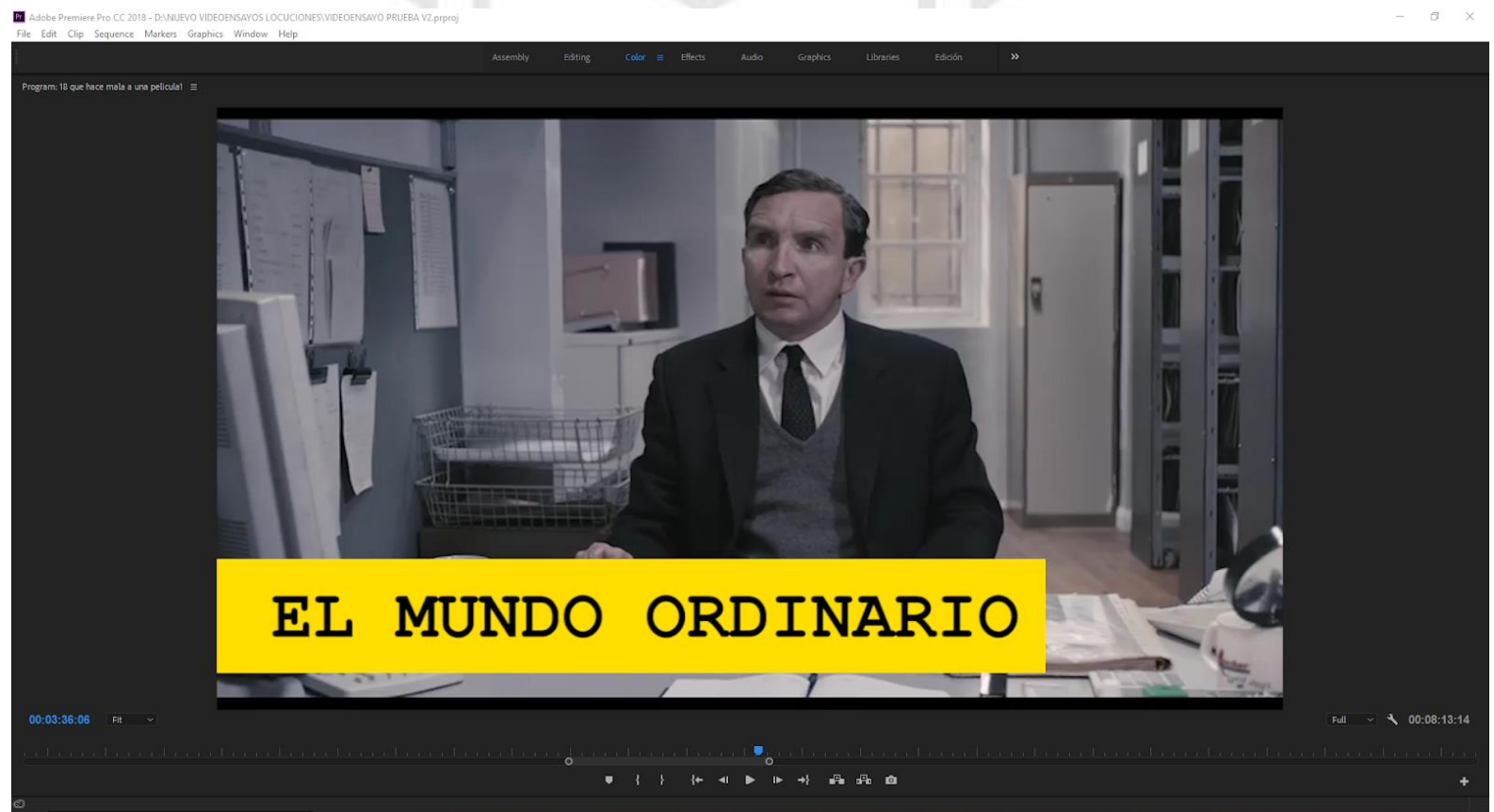


También, se utilizó el recurso de la pantalla negra, en ciertos momentos, para representar el pensamiento interno del personaje, y así darle un descanso momentáneo al discurso visual para que el espectador no se sature por el rápido ritmo del video. Cabe resaltar que, en este proceso varios elementos surgieron espontáneamente, producto del mismo proceso de edición; esto quiere decir que no se visualizan en el mismo guión del video, sino que se añadió como gag visual producto del proceso de post producción.

Posterior al aspecto visual de la parte didáctica, se trabajó la del videoblog, en la cual se trabajó un dramatizado de las acciones que se describen en la primera parte del audio del video completo. Para esto, se grabaron tomas de apoyo en la calle, en estas se buscó priorizar la imagen incógnita del personaje, es decir, se buscó evitar mostrar el rostro del personaje para generar un sentimiento de que este puede representar al espectador con respecto a problemas comunes como "lucha por la superación" o "incomprensión social", y así generar empatía con quien ve el video.

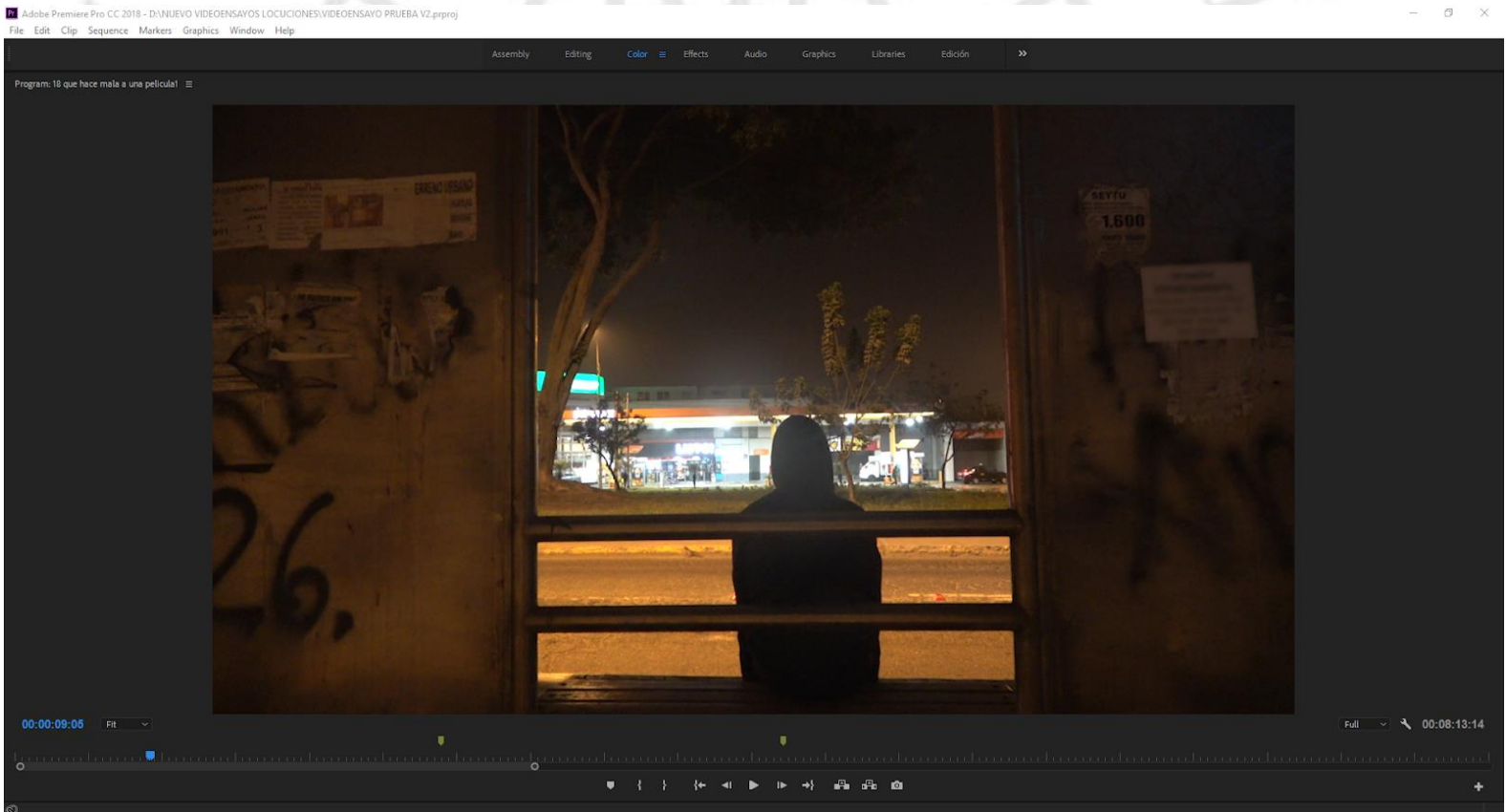

Paralelamente a la producción la parte visual del video, se hizo la careta de introducción del video, la cual separa la parte de videoblog de la parte didáctica. La careta consiste en la escritura de un guión ficticio, la cual cambia de una velocidad normal a una acelerada, esto se realiza para darle dinamismo y demostrar el largo trabajo que debe realizar un guionista al momento de trabajar.

Además, aparece una franja amarilla (emulando de nuevo al color amarillo de los post it) en donde sale "tipeado" el número y el nombre del capítulo. Este "tipeado" representa el tipeo que un 
guionista realiza al escribir, se añadió un sonido de tipeo de teclado para darle más realismo a la propuesta. Se presentó un avance al docente del curso y recomendó que saliera el nombre del canal de YouTube, plataforma en la cual se subirá la serie de videos acerca de temáticas de guión. Esto se tomó en consideración, y se agregó igualmente un texto "tipeado" con el nombre del canal, el cual sale en el vídeo, antes de la careta propuesta anteriormente.

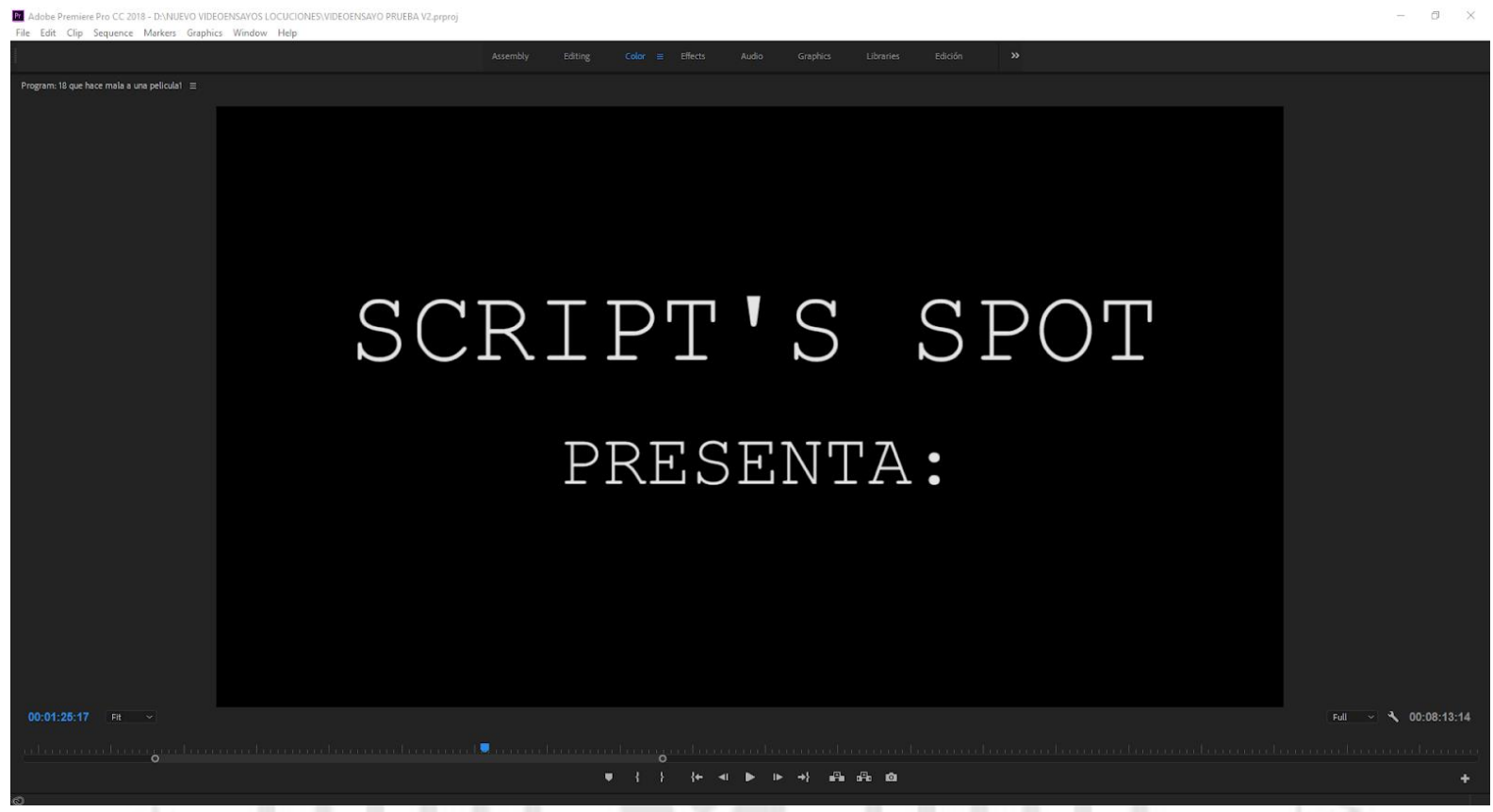

Además, con toda la producción del vídeo ya terminada, se definió que la parte de storytelling de la serie tenga como único elemento conductor al personaje narrador a lo largo de los capítulos, es decir, que no se hará una historia de inicio, nudo y final para el personaje, al menos en esta primera etapa. Se determinó que haya una primera temporada de 7 capítulos en los cuales se van a desarrollar sucesos que vayan ocurriendo en la vida del personaje y se relacionen directamente con el contenido o concepto del que se va a hablar en cada capítulo. La cantidad de capítulos a realizar se definió debido a las posibilidades de producción del proyecto y, a que es una prudente cantidad de capítulos para tener una respuesta del público acerca de si lo que se está realizando tiene futuro en el ámbito, y también que tan eficiente es la manera en que se está llevando a cabo el proyecto.

También, es importante mencionar que se relacionará la parte didáctica con la vida del personaje narrador y se generará una relación entre ellos, siendo prioritaria las temáticas de la parte didáctica, ya que la transmisión de conocimientos es un elemento principal y esencial del proyecto y, si bien la parte de videoblog también lo es, es conveniente que la narrativa de la historia del personaje se ajuste a los contenidos que se quieren enseñar con los videos, ya que la parte 
didáctica responde de manera directa a la alta demanda de contenidos sobre temáticas de guión y de cine, mientras que la del videoblog sirve más como un enganche con el espectador, y esta puede ser modificado de una manera más cómoda para que el proyecto pueda cumplir sus objetivos de la mejor manera.

Por otro lado, se eligió el nombre de la serie y del canal de YouTube; este se titulará "Script's Spot". Al inicio, se quería llamar "El rincón del guión" debido a que, personalmente, cuando trabajaba de guionista, siempre trabajaba en una esquina o un lugar reducido de la habitación, también hace alusión al poco reconocimiento que se le da a los guionistas en el mundo del cine, pues siempre se les da más crédito al director, a los actores o a otros personajes. El problema con ese nombre era que muchos, a quienes les comentaba la idea, relacionaban el título tentativo con "El rincón del vago", popular sitio web en donde se pone resúmenes educativos de varios textos educativos con el fin de facilitarle a los estudiantes el tener que leer ciertos libros o ensayos extensos, producto de esto se consideró que podría ser perjudicial para que se le dé la seriedad debida al proyecto. Por esa razón, se decidió realizar el cambio del español al inglés, para evitar comparativas despectivas hacia el producto final.

Además, se consideró incluir una imagen impactante que atraiga al espectador en los primeros 5 o 10 segundos del vídeo, como bien dicen Garcés y Miranda "Las analíticas de YouTube muestran que los primeros segundos de un vídeo son clave. Si a los 10 segundos no ha sucedido algo que capte la atención: siguiente video, siguiente canal. No se otorgan muchas oportunidades." (2019). Esto se pensó hacer, debido al inicio lento del video, pero al intentar incluir el elemento enganchador, según espectadores que visionaron esa versión, parecía una interrupción abrupta y que no iba de acorde al estilo del vídeo. Por ese motivo se decidió omitir esa parte del trabajo final.

Hasta este punto, se trabajó en el curso de Trabajo Profesional II. Después, para el Programa de Titulación de Verano 2020, se realizaron entrevistas a diversos profesores y se hizo un focus group. Los resultados, cambios y consideraciones de ese proceso se encuentran de manera más detallada en el capítulo VI de "Logros y Resultados".

En conclusión, este proceso tuvo un producto pensado y trabajado utilizando elementos que trabajan en favor de los dos objetivos generales del proyecto y que se diferencia de los contenidos tradicionales del rubro de enseñanza, al juntar dos formatos como los del video didáctico y el videoblog; estos, juntos con el storytelling del personaje, ayudan también a generar un enganche emocional y de entretenimiento con el espectador. 


\subsection{Sustentación}

De los puntos señalados anteriormente en el apartado de "Realización", hay algunos que son muy importantes para el proceso y, en este apartado, se hará énfasis en la base teórica y conceptual, por la cual han sido incluidos en el proyecto.

En primer lugar, la creación del personaje se debe al intento por cumplir el objetivo de entretenimiento, esto se realiza debido a que la búsqueda de la empatía y generar un enganche tanto cómico como emocional con el espectador. Como bien menciona Cohen, "la identificación con los personajes, la resonancia personal y la cercanía cultural juegan un papel principal para explicar el disfrute ocasionado por la ficción" (2001). También por ese motivo, la historia del personaje busca presentar problemas comunes con los cuales es fácil identificar como un "trabajo infeliz", "lucha por los sueños propios" o "injusticia", y esto genera que normalmente haya una respuesta positiva por parte del público en apoyo de quien sufre estos problemas.

Como parte complementaria al punto anterior, se añadió que en cada capítulo el personaje viva algún acontecimiento, el cual se relaciones directamente con el contenido didáctico del capítulo, para así acompañar al discurso y, generar interés y simpatía en el espectador. Esto ayuda a la generación de empatía y propone un ángulo diferencial del proyecto, ya que se juntan dos formatos como son los del videoblog y los videos didácticos. La combinación de estos permite utilizar la herramienta del storytelling, la cual permite "contar relatos personales, eventos históricos, o como una forma de enseñar un tópico en particular" (como se cita en Rosales y RoigVilla, 2017), para generar un vínculo más cercano con el espectador ya que el personaje se presenta como alguien próximo a éste, por medio del relato de los "problemas de su vida".

Por otro lado, en el planteamiento visual, se añadió el recurso de poner textos en videos para generar situaciones cómicas, en búsqueda de emular a los memes. Cabe destacar que "el meme tiene relación con un discurso caracterizado de forma icónica a través de símbolos e imágenes con el propósito de difundir ideas, sentimientos y emociones de forma viralizada por la red" (Muñoz, 2014). Lo dicho por Muñoz refuerza la intención de la utilización de este recurso con parentesco a los memes, ya que se busca generar el sentimiento de alegría o simplemente "causar gracia" con el vídeo propuesto, como parte de uno de los objetivos del proyecto que es entretener. Asimismo, para el objetivo de enseñar, se utilizó el recurso de palabras clave o términos específicos que hacen énfasis en ciertas partes importantes de información del discurso, estas se resaltan con los cuadros amarillos en donde se encuentran las palabras clave que ayudarán a retener mejor la información. 
Adicionalmente, se decidió utilizar, en el planteamiento visual del videoblog, tomas de apoyo que representan lo que narra el personaje. Esto se decidió utilizar, ya que busca apelar al sentimiento del espectador tanto por medio de las tomas de apoyo con un estilo sombrío y con la música con connotación de tristeza. También se eligió esta propuesta debido a que se quiere mantener cierto anonimato del rostro del personaje; ya que, al no tener un rostro claro, el público puede tener una concepción propia del personaje según cada espectador. Como se cita en Merleau "En la medida que el cuerpo permite una apertura perceptiva al mundo y a la "creación" de ese mundo, los otros dejan de ser un simple objeto y se constituyen en semejantes partícipes del mismo mundo sensible" (2009), tomando esto en cuenta, se puede afirmar que por medio de la percepción de este personaje, el espectador generará una imagen o creación de este en su imaginario, y dejará de ser un simple objeto o ente indiferente.

También, es importante resaltar nuevamente la elección de la temática del guión, pues como mencionaba Garrido (2015) "es fundamental en una propuesta artística.", lo cual demuestra su importancia en el proceso creativo, y como consecuencia, en un posible producto creativo. Entonces, al ser el guión un componente base en este proceso, es importante brindar explicación en conceptos claves para poder sacarles mejor provecho y poder tener un mejor producto final.

Por último, un punto importante es la presencia del personaje a lo largo de toda la temporada. Esto responde al modelo diferencial que se quiere proponer en este proyecto que, además de transmitir conocimiento, genere un enganche y una simpatía por la búsqueda del personaje por cumplir su objetivo. También se puede decir que "la búsqueda del disfrute es la principal razón por la que el espectador medio ve un producto audiovisual como las series, los concursos..." (Grandío, 2009); por lo cual este elemento ayudará en el cumplimiento del objetivo de entretenimiento, a través de la búsqueda del disfrute que tendrá el espectador acerca de la vida y la personalidad del personaje. 


\section{PLAN DE DIFUSIÓN Y MANTENIMIENTO}

Para el presente proyecto se aplicará un plan de medios que consistirá en utilizar diversas plataformas con el fin de distribuir y promocionar la serie de videos didácticos. Para esto se utilizaran 3 plataformas básicas.

- YouTube: Plataforma troncal, en la cual se publican los capítulos de la serie y se busca interacción con el público mediante comentarios en los videos acerca de las temáticas planteadas en estos. En esta primera etapa, la principal función de esta plataforma será la difusión del contenido creado, así como el posicionamiento de este contenido en la plataforma. Esto último, se buscará realizar a través de la interacción del canal con los seguidores en los comentarios, así como de un esfuerzo conjunto entre esta y las demás plataformas del proyecto.

Esta plataforma se caracteriza por la posibilidad de la publicación de videos, así como de “posts" en la pestaña de comunidad, en los cuales el creador de contenido puede realizar publicaciones para interactuar con los seguidores o dar noticias del canal; también cuenta con "stories" que duran 1 semana y por las cuales el creador puede generar contenido exclusivo para los usuarios seguidores de la plataforma o expresarse a través de estas stories.

En este proyecto, se utilizarán los "posts" para dar noticias importantes relacionadas con el canal, así como para plantear temas de discusión en los cuales se buscará identificar temas de interés del público y opiniones, y también con el fin de generar cierta interacción. Las stories serán utilizadas con el fin de entretener, así sacando provecho a la personalidad del personaje y generando simpatía en el espectador. Estos recursos se pueden encontrar en la página de inicio de YouTube o en la pestaña de comunidad dentro del mismo canal.

En una etapa más avanzada del proyecto, se planea utilizar recursos de la plataforma como las "lista de reproducción" para crear diferente tipo de contenido y las personas puedan seleccionar que tipo de contenidos quieren ver, entre los tipos de contenidos posibles del canal pueden estar: "serie de videos didácticos", "video críticas", "preguntas y respuestas", "colaboraciones con otros youtubers", etc. Asimismo, en esta etapa más avanzada, se buscará hacer colaboraciones con otros creadores de contenido que sigan el mismo rubro del proyecto, así también ayudando en el posicionamiento del canal y a llegar a un público más global, al realizar colaboraciones con youtubers o influencers de 
otros países. Por último, se buscará conseguir sponsors que apoyen económicamente al proyecto por medio de publicidad o sorteos.

- Instagram: Plataforma auxiliar, en la cual el formato que se utiliza son las fotografías e imágenes que se publican. La cuenta de Instagram será del canal "Script's Spot”, pero, tanto los escritos como las imágenes, contarán con el estilo y la personalidad del personaje. Se ha elegido que la cuenta sea del canal, ya que genera un posicionamiento visual en el espectador, debido al logo y al estilo visual, así sacando provecho de la naturaleza de la plataforma. Instagram tiene como fin promocionar el canal de YouTube y generar contenido de valor para el público de Instagram.

La promoción del canal se llevará a cabo por medio de pequeños videos que promocionan los capítulos del canal, así como imágenes que hagan alusión a los temas tratados en los videos del canal de YouTube (estas pueden ser antes o después de un capítulo), además se invitará a los seguidores a ver el último video, cuyo enlace estará en el link de la biografía de la FanPage. Asimismo, se utilizarán los memes para generar simpatía, estos aparecerán tanto en publicaciones como en "stories". También, la generación de contenido de valor se creará a partir de pequeños videos que contendrán un consejo o tip adicional, con respecto al último video publicado en el canal, para así potenciar el uso de esta plataforma. El pequeño video, no pasará del minuto de duración.

Finalmente, se utilizará publicidad dirigida al público objetivo, esta se realizará para los pequeños videos promocionales de los capítulos estrenos, para así generar expectativa en el espectador.

- Twitter: Plataforma auxiliar que tendrá como principal fin generar interacción entre el usuario y el público. La cuenta de Twitter será del personaje "Sr. Script", para que el contacto entre el creador de contenido y el seguidor sea más cercano.

La generación de interacción se realizará por medio de cuestionamientos o preguntas que se realicen en Twitter para que los seguidores den su opinión sobre un tema determinado. Para cumplir con el propósito de la plataforma, se deberá tener una alta interacción con los seguidores respondiendo dudas o sugerencias que puedan surgir. En este proceso, se puede encontrar nuevas ideas para generar nuevo contenido del canal, ya que habría un mejor conocimiento de los gustos del espectador, que se puede traducir en nuevos tipos de videos que estén dispuestos a ver. 
Por otro lado, también se utilizará la plataforma para dar el punto de vista del personaje y que esto incite al debate y/o a la conversación sobre el o los temas planteados. Además, se utilizarán los "hilos" de la plataforma para hacer diferentes tipos de contenidos extra para los usuarios de esa plataforma (Rankings de películas, críticas, tips de guión, etc.)

Con las plataformas ya explicadas, se detallará el proceso de trabajo en redes con respecto a los capítulos que se van subiendo a la plataforma de YouTube.

\subsection{Estrategia para la publicación del primer capítulo}

En primer lugar, para antes del posteo del primer capítulo, se tendrán creadas las plataformas de YouTube y de Instagram, la primera acción que se tomará será la de crear y postear en Instagram, un pequeño video de unos 30 segundos como máximo, invitando al público a estar atento al próximo estreno del video; este será el primero de una serie de cuatro pequeños videos.

Para el primer video promocional de Instagram se tiene pensado que se use la frase "¿Alguna vez escuchaste de un chico que quiso ser guionista, pero no le salió?, acompáñanos a ver esta triste historia", así buscando apelar a la comedia y a la simpatía del espectador, además al final se tiene pensado poner los días faltantes para el estreno del video (Un countdown) y poner el logo del canal. El resto de videos consiguientes hasta el estreno del primer video capítulo, acerca de la imagen de apertura, será del mismo estilo y tono humorístico. El primer video de Instagram se publicará 4 días antes del estreno del primer capítulo en YouTube. Es decir, se publicaran 4 pequeños videos, en total.

Asimismo, en las "stories" de la FanPage en Instagram se pondrán algunos memes referidos a la temática de guión, para que el usuario pueda entender la temática de la página. En el día del estreno del primer episodio en YouTube, se posteará una imagen atractiva del video y se invitará a que los usuarios entren al link de la biografía de la FanPage. Cabe destacar que tanto para el primer video promocional de Instagram y el post del día del estreno se tiene planteado pagar por publicidad para que salga en el inicio de un público objetivo determinado, para que así la publicación llegué a personas con gustos parecidos al del público objetivo.

Pasando a YouTube, el primer video será publicado y, en el mismo, se hará un post avisando de la publicación en la pestaña de comunidad, asimismo, se invitará a los espectadores a dejar sus comentarios para iniciar un diálogo acerca de la temática propuesta. Posterior a esto, en Instagram, se publicará una foto recordando a los usuarios acerca del video. Una semana después, se posteará un video en Instagram, de 1 minuto como máximo, donde se dé un consejo adicional con respecto a la temática tratada en el último video (nuevo contenido de valor). Mientras tanto, 
se utilizarán las "stories" para poner memes acerca del último video, así como preguntas y encuestas para conocer mejor al público y sus posibles gustos. Este proceso se repetiría una y otra vez, con el fin de promocionar y recabar información del público acerca de posibles gustos que, luego, pueden traducirse en nuevos contenidos para el proyecto.

En el capítulo 2 o 3, entrará la plataforma de Twitter, ya que al ser la cuenta de Twitter personal del personaje, es conveniente que el público de Instagram y YouTube conozcan un poco al narrador de estos videos, para luego "enganchar" con él en otra plataforma. En esta, como ya se mencionó, se plantearán preguntas y cuestionamientos acerca de la temática de guión y del cine en general, así habiendo una comunicación bidireccional más efusiva. Esta plataforma, ayudará tanto en la etapa previa a la publicación de los capítulos, como en la posterior. Esto sucederá una vez que el proyecto ya esté en su segundo o tercer capítulo.

\subsection{Flujo de trabajo}

Es importante resaltar que los capítulos se tienen pensado publicar en YouTube cada 2 o 3 semanas, dependiendo del flujo natural de trabajo que requiera cada video. Después del estreno del primer video, con una cantidad de personas ya fidelizadas al contenido y con cierto conocimiento de la temática del canal, se tiene pensado dividir el flujo de trabajo en redes sociales en 3 fases:

\subsubsection{Etapa pre-publicación:}

- En esta primera etapa, se divide el trabajo de la siguiente manera:

a. Instagram: En primer lugar, se postea un pequeño video de unos 30 segundos máximo, que anticipa de cierta manera el posible contenido del siguiente episodio, esto siempre con un tono humorístico, se tiene pensado en denominar a este video "El vistazo del próximo capítulo". Cabe destacar que este es solo un video por capítulo, y no un "countdown" de varios mini-videos como se realizó para el video piloto. Asimismo, también este pequeño anticipo será acompañado por una foto o imagen representativa del "making of" del episodio que viene.

Además, se utilizará las "stories" para plantear preguntas o hacer encuestas con referencia a los temas tratados en los capítulos (tantos anteriores como próximos) con el fin de generar interacción y tener una mejor panorama de nuevas ideas o nuevo tipo de contenido que le podría gustar al público seguidor del proyecto, siempre y cuando vaya en línea con la temática planteada. Además, en las 
"stories" se incluirán memes del mundo del cine como fin de seguir la línea de entretenimiento del proyecto

b. Twitter: En esta plataforma, se planteará cuestionamientos sobre diferentes temáticas referidas al cine en general, con el estilo del personaje más presente. También, el propósito de esto es que la comunicación sea más fluida y haya una dinámica de feedback más directa entre los seguidores y el creador de contenido; además se pueden intercambiar ideas sobre cómo mejorar el contenido de la serie y de los próximos capítulos.

También, se puede aprovechar la herramienta de los "hilos" de Twitter (secuencia de Tweets que juntos componen un discurso más largo) para hacer rankings, reseñas, críticas, consejos rápidos de guión, entre otros, para que las personas puedan comentar sus impresiones o dudas, y así; intercambiar ideas.

c. YouTube: En la pestaña de comunidad, se anunciarán cambios de programación en el canal cuando estos sucedan, como por ejemplo el cambio de fecha u hora de publicación de un video, y se dará las explicaciones del caso. Asimismo, se utilizarán las "stories" que son de una semana para mostrar material del "making of" de los videos y/o memes de acorde a la temática. También, se evalúa anunciar, un día antes, el estreno de cada capítulo, para que así el público se entere del futuro contenido que se publicará.

\subsubsection{Publicación del video:}

- En esta segunda etapa, se divide el trabajo de la siguiente manera:

a. Instagram: El día de la publicación del video se avisará a los seguidores por medio de un "post" que el nuevo capítulo ya está disponible en el canal de YouTube. El "post" consistirá en un fotograma atractivo extraído del capítulo, este será acompañado por una pequeña descripción en donde se invite al seguidor a dar clic en el link de la biografía de la FanPage, el cual lo llevará directamente al video del nuevo capítulo en YouTube. Asimismo, se avisará por las "stories" acerca del nuevo video para que tenga más alcance y visibilidad para los seguidores.

b. Twitter: Se avisará por medio de un tweet la publicación del video y se pondrá el enlace directo en dicho tweet para que el seguidor solo tenga que dar un clic para llegar al video. 
c. YouTube: En la pestaña de comunidad, se publicará el estreno del capítulo y se facilitará un enlace para ir a verlo. Asimismo, en el mismo video, se incentivará a los espectadores para que escriban su opinión en los comentarios, para así mantener la interacción con los espectadores con respecto a sus opiniones con respecto al producto.

\subsubsection{Etapa post-publicación}

- En esta tercera etapa, se divide el trabajo de la siguiente manera:

a. Instagram: Después de la publicación del capítulo en YouTube, se pondrá un "post" recordando acerca del capítulo para que el público vaya a verlo (este post se buscará promocionar para que tenga mayor alcance). Además, se publicará un pequeño video, de un minuto máximo de duración, dando un consejo extra sobre cómo usar el recurso de guión explicado en el último video, así creando un contenido de valor extra en esta plataforma.

b. Twitter: Comentar acerca del vídeo, publicar estados o referencias con respecto a la parte didáctica y la del storytelling. En el caso de la parte didáctica, se comentaría, principalmente, para ver que otro tipo de contenido se puede producir que sea del gusto del público; mientras que en la parte del storytelling, se comentaría y habría interacción con el público para corroborar que la historia del personaje encaja bien en el discurso presentado en el capítulo, y si va por buen camino.

c. YouTube: Por medio de la pestaña de comunidad, preguntar a los seguidores sus opiniones acerca del último vídeo y de qué otros temas les gustaría que se hable en los siguientes capítulos. De igual manera, revisar los comentarios puestos en los videos para recabar la mayor información posible e interactuar con los seguidores si es que tienen alguna duda o consulta acerca del capítulo

También es importante mencionar el proceso del canal secundario para evitar problemas con el canal principal de "Script's Spot" y la política de derechos de autor que tiene YouTube. El proceso sería el siguiente: 
1. Primero, se editaría el video tal como se quiere publicar, esto teniendo en cuenta algunas maneras de evitar el asunto del Copyright como evitar poner extractos muy largos de las películas; voltear las extractos de películas que son largos, pero necesarios; poner interferencias que modifiquen la imagen; etc.

2. Luego, se publicaría en el canal secundario y, en caso salga alguna alarma o notificación en relación con los derechos de autor, se revisa el video

3. Después, se iría de nuevo al programa "Adobe Premiere" para corregir lo necesario.

4. Luego, se publicaría de nuevo en el canal secundario. Este proceso se repetiría hasta que no aparezca ninguna alarma acerca de infringir el Copyright.

5. Finalmente, con el video ya habilitado, se publicaría en el canal principal de "Script's Spot"

Este proceso se realizaría para no tener problemas con el Content ID, y para las personas que buscan el contenido con la intención de desmonetizar el video, se trataría de no poner nombres de películas en los títulos de los capítulos.

También, es importante hacer notar que el proyecto contará con un logo (el cual se promocionará por todas las plataformas que incluye el proyecto) que será lo siguiente: será un dibujo de una persona con casaca y capucha negra (Sr. Script) con una computadora. El Sr Script estará dando la espalda y estará sentado en una silla de director con el nombre "Script's Spot" en la parte de atrás. Esta imagen resume la personalidad del personaje, así como el estilo y temática del canal.

Finalmente, se ha planteado una parrilla de contenidos que van desde el primer hasta el cuarto capítulo, para así graficar cómo sería el ritmo de trabajo en cuanto a días de la semana. Para entender este cuadro tienen que tener en cuenta algunos puntos:

- Se tendrán preparados entre 4 a 5 capítulos preparados antes de iniciar con el proyecto.

- Se plantea que la fecha de estreno del primer capítulo sea el 1 ro de Junio de 2020. Esta fecha puede variar. 
- En la parrilla se incluye el proceso del canal secundario para organizar mejor los tiempos del proyecto

- Los capítulos están resaltados de color amarillo, mientras que los episodios extras de 1 minuto de Instagram están resaltados en verde.

- Se incluye las actividades realizadas en las plataformas de YouTube, Instagram y Twitter. Esta última se activa después del segundo capítulo.

- Las fechas son referenciales, pueden variar según el feedback recibido en las diferentes plataformas.

(La parrilla de contenidos inicia en la siguiente página)

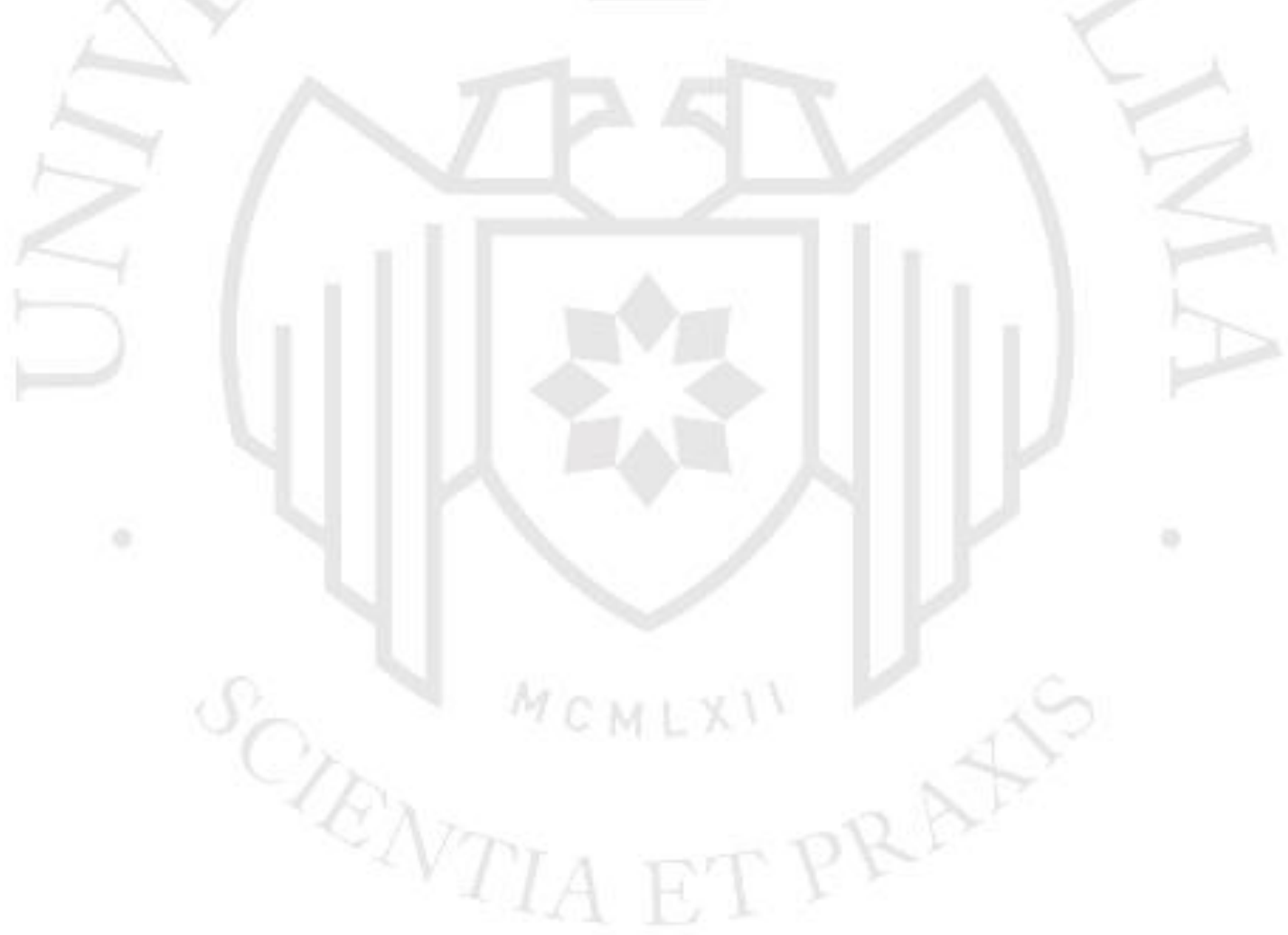




\subsection{Parrilla de contenidos}

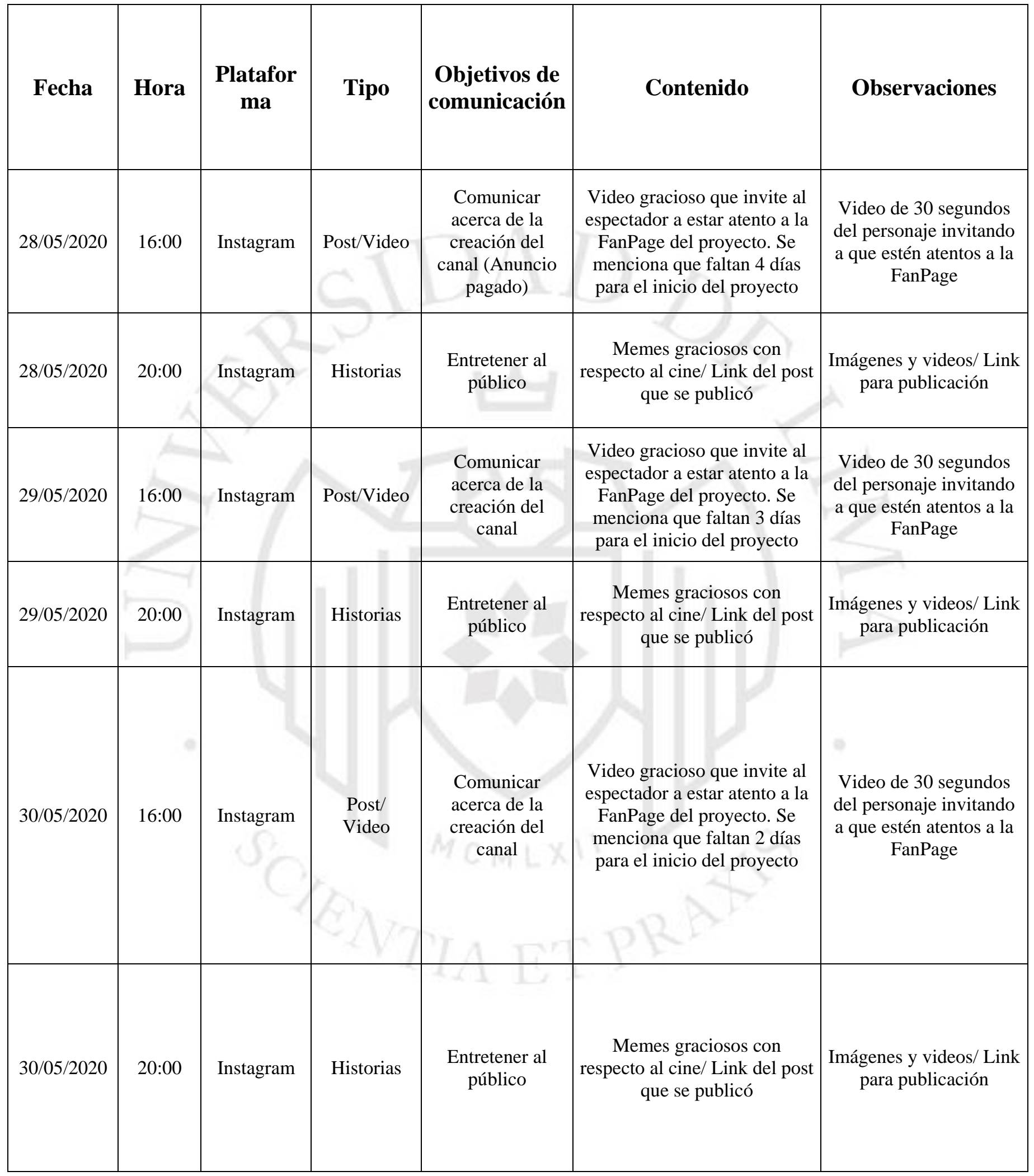




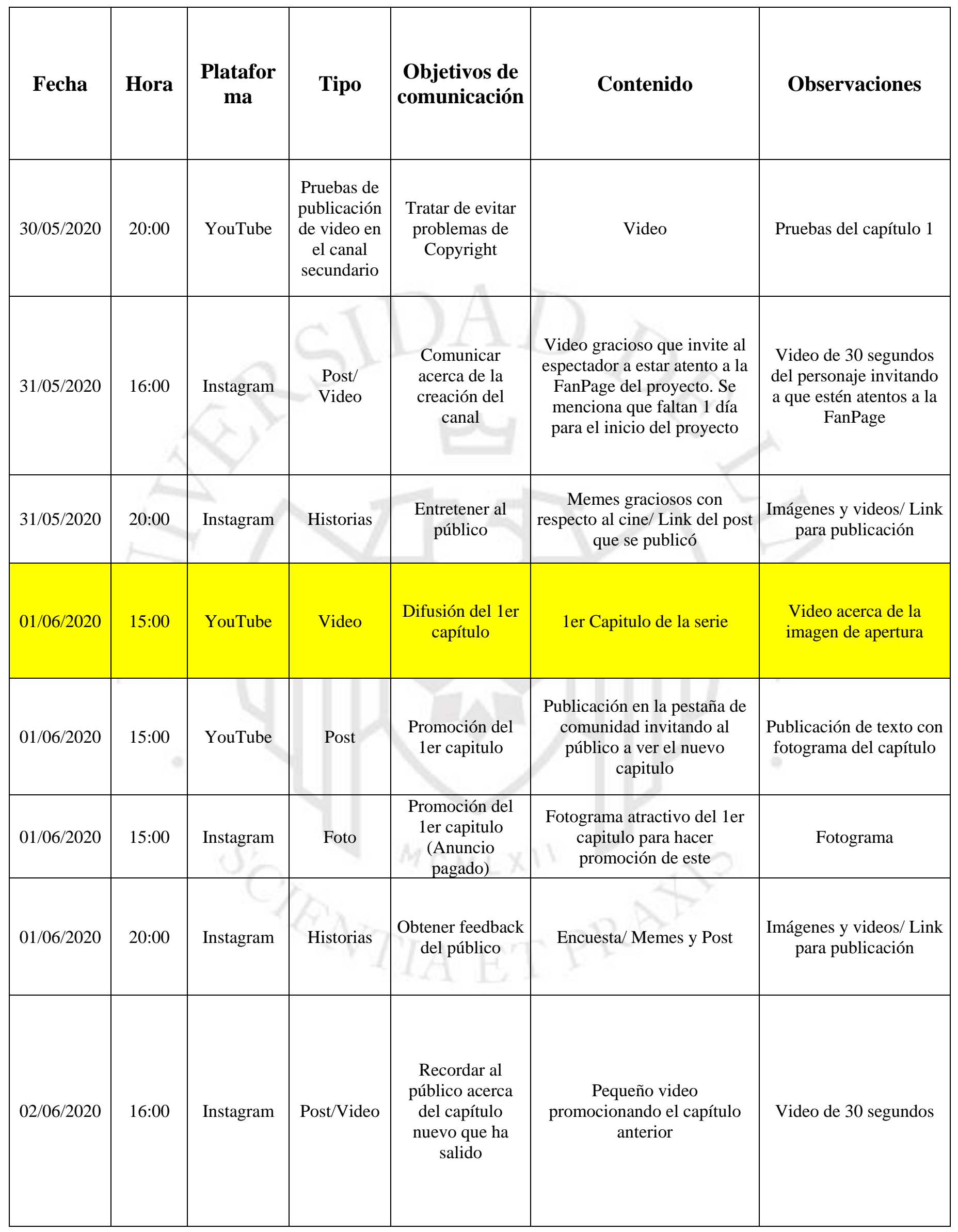




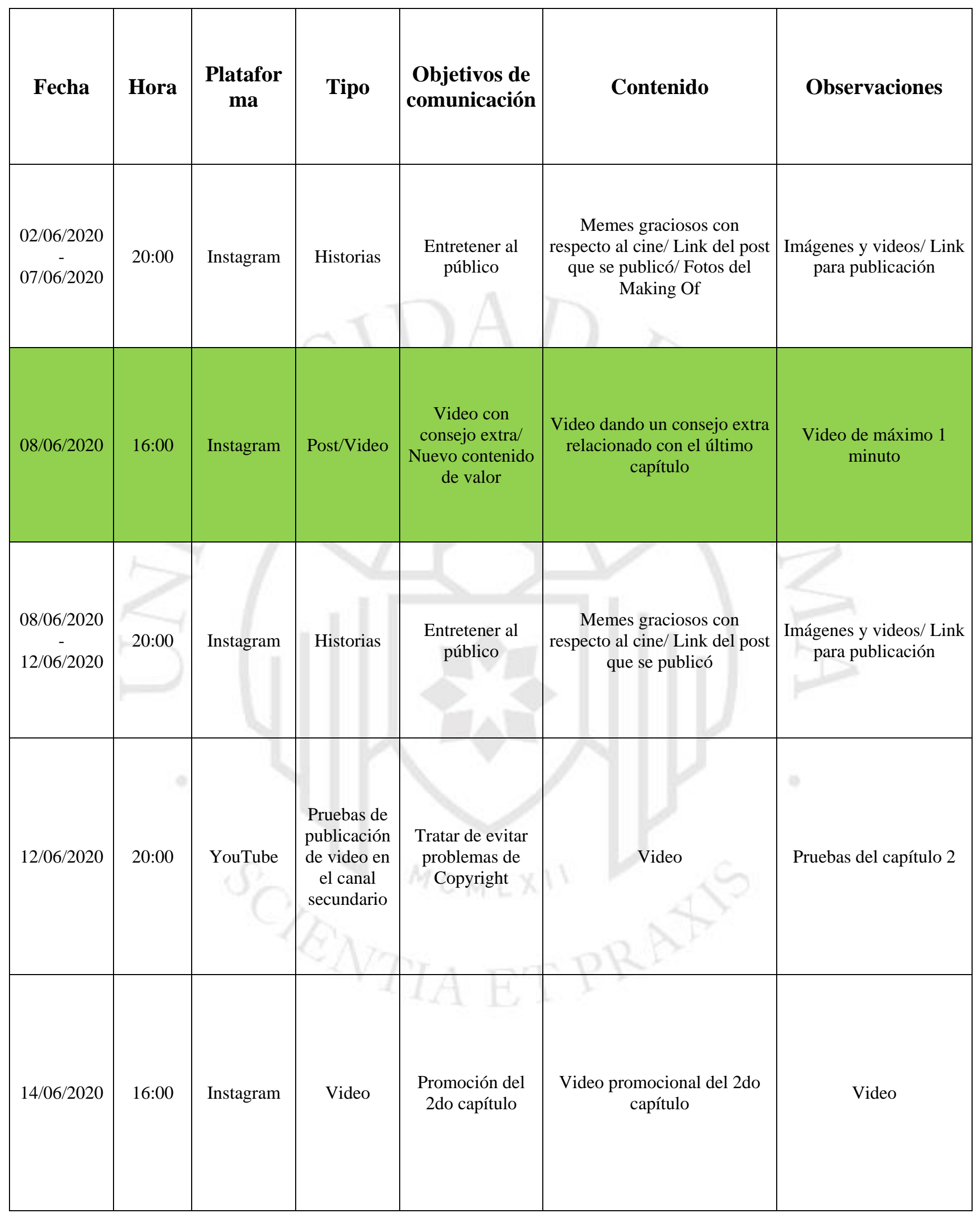




\begin{tabular}{|c|c|c|c|c|c|c|}
\hline Fecha & Hora & $\begin{array}{l}\text { Platafor } \\
\text { ma }\end{array}$ & Tipo & $\begin{array}{l}\text { Objetivos de } \\
\text { comunicación }\end{array}$ & Contenido & Observaciones \\
\hline $14 / 06 / 2020$ & 20:00 & Instagram & Instagram & $\begin{array}{l}\text { Entretener al } \\
\text { público }\end{array}$ & $\begin{array}{l}\text { Memes graciosos con } \\
\text { respecto al cine/ Link del post } \\
\text { que se publicó }\end{array}$ & $\begin{array}{l}\text { Imágenes y videos/ Link } \\
\text { para publicación }\end{array}$ \\
\hline $15 / 06 / 2020$ & 15:00 & YouTube & Video & $\begin{array}{l}\text { Difusión del 2do } \\
\text { capítulo }\end{array}$ & 2do Capitulo de la serie & $\begin{array}{l}\text { Video acerca de la } \\
\text { ayuda providencial }\end{array}$ \\
\hline $15 / 06 / 2020$ & 15:00 & YouTube & Post & $\begin{array}{l}\text { Promoción del } \\
\text { 2do capitulo }\end{array}$ & $\begin{array}{l}\text { Publicación en la pestaña de } \\
\text { comunidad invitando al } \\
\text { público a ver el nuevo } \\
\text { capitulo }\end{array}$ & $\begin{array}{l}\text { Publicación de texto con } \\
\text { fotograma del capítulo }\end{array}$ \\
\hline $15 / 06 / 2020$ & 15:00 & Instagram & Foto & $\begin{array}{l}\text { Promoción del } \\
\text { 2do capitulo } \\
\text { (Anuncio } \\
\text { pagado) }\end{array}$ & $\begin{array}{l}\text { Fotograma atractivo del 2do } \\
\text { capitulo para hacer } \\
\text { promoción de este }\end{array}$ & Fotograma \\
\hline $15 / 06 / 2020$ & 20:00 & Instagram & Historias & $\begin{array}{l}\text { Obtener feedback } \\
\text { del público }\end{array}$ & Encuesta/ Memes y Post & $\begin{array}{l}\text { Imágenes y videos/ Link } \\
\text { para publicación }\end{array}$ \\
\hline
\end{tabular}




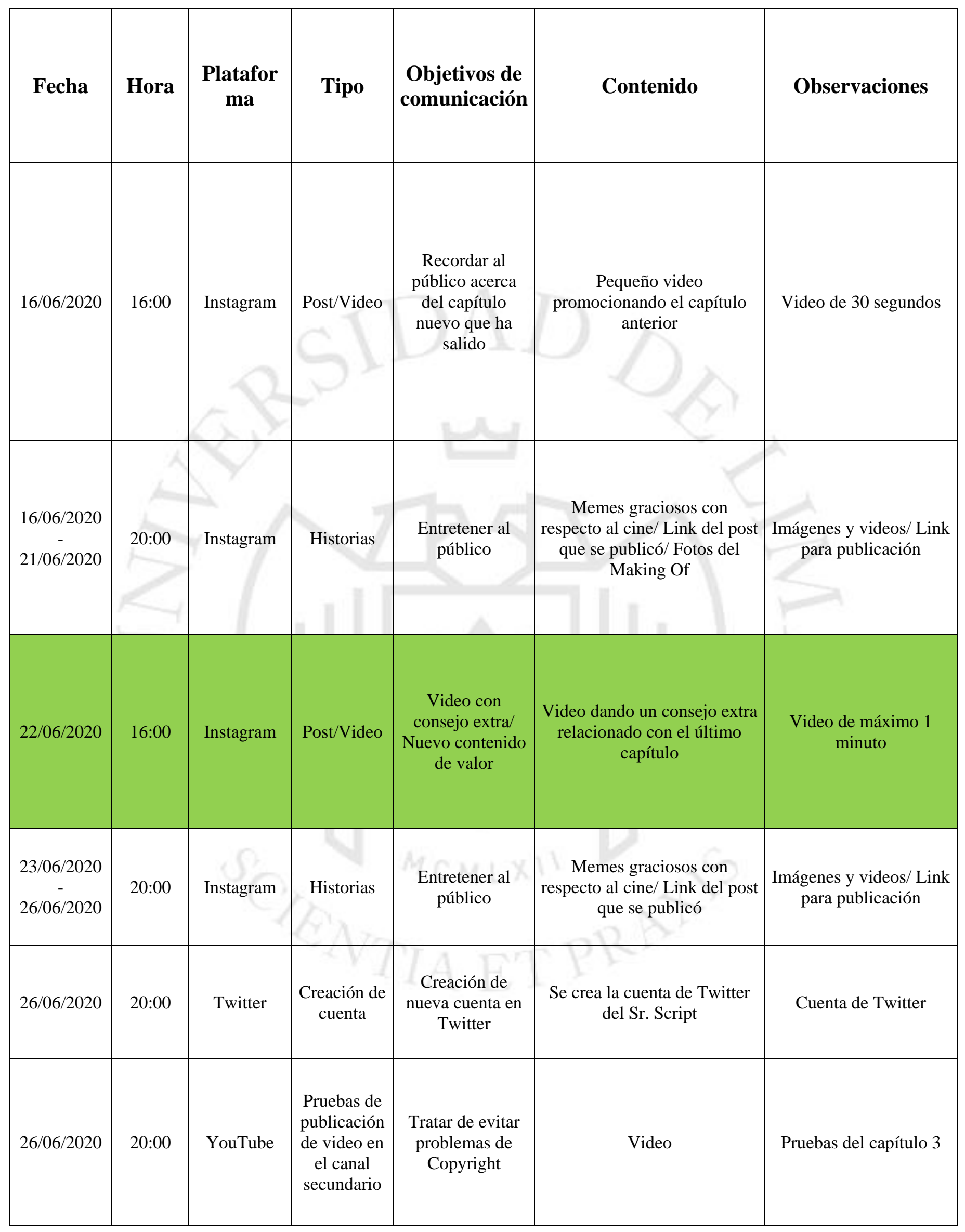




\begin{tabular}{|c|c|c|c|c|c|c|}
\hline Fecha & Hora & $\begin{array}{l}\text { Platafor } \\
\text { ma }\end{array}$ & Tipo & $\begin{array}{l}\text { Objetivos de } \\
\text { comunicación }\end{array}$ & Contenido & Observaciones \\
\hline $28 / 06 / 2020$ & $16: 00$ & Instagram & Video & $\begin{array}{l}\text { Promoción del } \\
\text { 3er capítulo }\end{array}$ & $\begin{array}{l}\text { Video promocional del 3er } \\
\text { capítulo }\end{array}$ & Video \\
\hline $29 / 06 / 2020$ & $15: 00$ & YouTube & Video & $\begin{array}{l}\text { Difusión del 3er } \\
\text { capítulo }\end{array}$ & 3er Capitulo de la serie & $\begin{array}{l}\text { Video acerca del } \\
\text { momento "Todo está } \\
\text { perdido". En este } \\
\text { capítulo, se invita a los } \\
\text { espectadores a seguir la } \\
\text { nueva cuenta de Twitter. }\end{array}$ \\
\hline $29 / 06 / 2020$ & $15: 00$ & YouTube & Post & $\begin{array}{l}\text { Promoción del } \\
\text { 3er capitulo }\end{array}$ & $\begin{array}{c}\text { Publicación en la pestaña de } \\
\text { comunidad invitando al } \\
\text { público a ver el nuevo } \\
\text { capitulo }\end{array}$ & $\begin{array}{l}\text { Publicación de texto con } \\
\text { fotograma del capítulo }\end{array}$ \\
\hline $29 / 06 / 2020$ & $15: 00$ & Instagram & Foto & $\begin{array}{l}\text { Promoción del } \\
\text { 3er capitulo } \\
\text { (Anuncio } \\
\text { pagado) }\end{array}$ & $\begin{array}{l}\text { Fotograma atractivo del 3er } \\
\text { capitulo para hacer } \\
\text { promoción de este }\end{array}$ & Fotograma \\
\hline $29 / 06 / 2020$ & $15: 00$ & Twitter & Post & $\begin{array}{l}\text { Promoción del } \\
\text { 3er capitulo }\end{array}$ & $\begin{array}{l}\text { Fotograma atractivo del 3er } \\
\text { capitulo para hacer } \\
\text { promoción de este }\end{array}$ & Post con foto \\
\hline $29 / 06 / 2020$ & 20:00 & Instagram & Historias & $\begin{array}{l}\text { Obtener feedback } \\
\text { del público }\end{array}$ & Encuesta/ Memes y Post & $\begin{array}{l}\text { Imágenes y videos/ Link } \\
\text { para publicación }\end{array}$ \\
\hline $29 / 06 / 2020$ & 20:00 & Twitter & Tweet & $\begin{array}{l}\text { Obtener feedback } \\
\text { del público }\end{array}$ & $\begin{array}{l}\text { Pregunta o cuestionamiento } \\
\text { sobre el último tema tratado } \\
\text { en el capítulo más reciente }\end{array}$ & Tweet del Sr. Script \\
\hline
\end{tabular}




\begin{tabular}{|c|c|c|c|c|c|c|}
\hline Fecha & Hora & $\begin{array}{l}\text { Platafor } \\
\text { ma }\end{array}$ & Tipo & $\begin{array}{l}\text { Objetivos de } \\
\text { comunicación }\end{array}$ & Contenido & Observaciones \\
\hline $30 / 06 / 2020$ & $16: 00$ & Instagram & Post/Video & $\begin{array}{l}\text { Recordar al } \\
\text { público acerca } \\
\text { del capítulo } \\
\text { nuevo que ha } \\
\text { salido }\end{array}$ & $\begin{array}{l}\text { Pequeño video } \\
\text { promocionando el capítulo } \\
\text { anterior }\end{array}$ & Video de 30 segundos \\
\hline $\begin{array}{c}30 / 06 / 2020 \\
- \\
05 / 07 / 2020\end{array}$ & $20: 00$ & Instagram & Historias & $\begin{array}{l}\text { Entretener al } \\
\text { público }\end{array}$ & \begin{tabular}{|c|} 
Memes graciosos con \\
respecto al cine/ Link del post \\
que se publicó/ Fotos del \\
Making Of
\end{tabular} & $\begin{array}{l}\text { Imágenes y videos/ Link } \\
\text { para publicación }\end{array}$ \\
\hline $\begin{array}{c}30 / 06 / 2020 \\
- \\
05 / 07 / 2020\end{array}$ & 20:00 & Twitter & Tweet & $\begin{array}{l}\text { Entretener al } \\
\text { público y obtener } \\
\text { feedback }\end{array}$ & $\begin{array}{l}\text { Pregunta o cuestionamiento } \\
\text { sobre el último tema tratado } \\
\text { en el capítulo más reciente }\end{array}$ & Tweet del Sr. Script \\
\hline $6 / 06 / 2020$ & $16: 00$ & Instagram & Post/Video & $\begin{array}{c}\text { Video con } \\
\text { consejo extra/ } \\
\text { Nuevo contenido } \\
\text { de valor }\end{array}$ & $\begin{array}{l}\text { Video dando un consejo extra } \\
\text { relacionado con el último } \\
\text { capítulo }\end{array}$ & $\begin{array}{l}\text { Video de máximo } 1 \\
\text { minuto }\end{array}$ \\
\hline $\begin{array}{c}7 / 07 / 2020 \\
- \\
10 / 07 / 2020\end{array}$ & $20: 00$ & Instagram & Historias & $\begin{array}{l}\text { Entretener al } \\
\text { público }\end{array}$ & $\begin{array}{c}\text { Memes graciosos con } \\
\text { respecto al cine/ Link del post } \\
\text { que se publicó }\end{array}$ & $\begin{array}{l}\text { Imágenes y videos/ Link } \\
\text { para publicación }\end{array}$ \\
\hline $\begin{array}{c}7 / 07 / 2020 \\
- \\
10 / 07 / 2020\end{array}$ & $20: 00$ & Twitter & Tweet & $\begin{array}{l}\text { Entretener al } \\
\text { público y obtener } \\
\text { feedback }\end{array}$ & $\begin{array}{l}\text { Pregunta o cuestionamiento } \\
\text { sobre el último tema tratado } \\
\text { en el capítulo más reciente }\end{array}$ & Tweet del Sr. Script \\
\hline $10 / 07 / 2020$ & $20: 00$ & YouTube & $\begin{array}{l}\text { Pruebas de } \\
\text { publicación } \\
\text { de video en } \\
\text { el canal } \\
\text { secundario }\end{array}$ & $\begin{array}{l}\text { Tratar de evitar } \\
\text { problemas de } \\
\text { Copyright }\end{array}$ & & Pruebas del capítulo 4 \\
\hline $12 / 07 / 2020$ & $16: 00$ & Instagram & Video & $\begin{array}{l}\text { Promoción del } \\
\text { 4to capítulo }\end{array}$ & $\begin{array}{l}\text { Video promocional del } 4 \text { to } \\
\text { capítulo }\end{array}$ & Video \\
\hline
\end{tabular}




\begin{tabular}{|c|c|c|c|c|c|c|}
\hline Fecha & Hora & $\begin{array}{l}\text { Platafor } \\
\text { ma }\end{array}$ & Tipo & $\begin{array}{l}\text { Objetivos de } \\
\text { comunicación }\end{array}$ & Contenido & Observaciones \\
\hline $13 / 07 / 2020$ & $15: 00$ & YouTube & Video & $\begin{array}{l}\text { Difusión del 4to } \\
\text { capítulo }\end{array}$ & 4to Capitulo de la serie & $\begin{array}{l}\text { Video acerca de "El } \\
\text { Conflicto" }\end{array}$ \\
\hline $13 / 07 / 2020$ & $15: 00$ & YouTube & Post & $\begin{array}{l}\text { Promoción del } \\
\text { 4to capitulo }\end{array}$ & $\begin{array}{c}\text { Publicación en la pestaña de } \\
\text { comunidad invitando al } \\
\text { público a ver el nuevo } \\
\text { capitulo }\end{array}$ & $\begin{array}{l}\text { Publicación de texto con } \\
\text { fotograma del capítulo }\end{array}$ \\
\hline $13 / 07 / 2020$ & $15: 00$ & Instagram & Foto & $\begin{array}{l}\text { Promoción del } \\
\text { 4to capitulo } \\
\text { (Anuncio } \\
\text { pagado) }\end{array}$ & $\begin{array}{l}\text { Fotograma atractivo del 4to } \\
\text { capitulo para hacer } \\
\text { promoción de este }\end{array}$ & Fotograma \\
\hline $13 / 07 / 2020$ & $15: 00$ & Twitter & Post & $\begin{array}{l}\text { Promoción del } \\
\text { 4to capitulo }\end{array}$ & $\begin{array}{c}\text { Fotograma atractivo del 4to } \\
\text { capitulo para hacer } \\
\text { promoción de este }\end{array}$ & Post con foto \\
\hline $13 / 07 / 2020$ & $20: 00$ & Instagram & Historias & $\begin{array}{c}\text { Obtener feedback } \\
\text { del público }\end{array}$ & Encuesta/ Memes y Post & $\begin{array}{l}\text { Imágenes y videos/ Link } \\
\text { para publicación }\end{array}$ \\
\hline $13 / 07 / 2020$ & $20: 00$ & Twitter & Tweet & $\begin{array}{l}\text { Obtener feedback } \\
\text { del público }\end{array}$ & $\begin{array}{l}\text { Pregunta o cuestionamiento } \\
\text { sobre el último tema tratado } \\
\text { en el capítulo más reciente }\end{array}$ & Tweet del Sr. Script \\
\hline $14 / 07 / 2020$ & $16: 00$ & Instagram & Post/Video & $\begin{array}{c}\text { Recordar al } \\
\text { público acerca } \\
\text { del capítulo } \\
\text { nuevo que ha } \\
\text { salido } \\
\end{array}$ & $\begin{array}{c}\text { Pequeño video } \\
\text { promocionando el capítulo } \\
\text { anterior }\end{array}$ & Video de 30 segundos \\
\hline $\begin{array}{c}15 / 07 / 2020 \\
- \\
19 / 07 / 2020\end{array}$ & $20: 00$ & Instagram & Historias & $\begin{array}{l}\text { Entretener al } \\
\text { público }\end{array}$ & $\begin{array}{c}\text { Memes graciosos con } \\
\text { respecto al cine/ Link del post } \\
\text { que se publicó/ Fotos del } \\
\text { Making Of }\end{array}$ & $\begin{array}{l}\text { Imágenes y videos/ Link } \\
\text { para publicación }\end{array}$ \\
\hline $\begin{array}{c}15 / 07 / 2020 \\
- \\
19 / 07 / 2020\end{array}$ & 20:00 & Twitter & Tweet & $\begin{array}{c}\text { Entretener al } \\
\text { público y obtener } \\
\text { feedback }\end{array}$ & $\begin{array}{l}\text { Pregunta o cuestionamiento } \\
\text { sobre el último tema tratado } \\
\text { en el capítulo más reciente }\end{array}$ & Tweet del Sr. Script \\
\hline $20 / 07 / 2020$ & $16: 00$ & Instagram & Post/Video & $\begin{array}{l}\text { Video con } \\
\text { consejo extra/ } \\
\text { Nuevo contenido } \\
\text { de valor }\end{array}$ & $\begin{array}{l}\text { Video dando un consejo extra } \\
\text { relacionado con el último } \\
\text { capítulo }\end{array}$ & $\begin{array}{c}\text { Video de máximo } 1 \\
\text { minuto }\end{array}$ \\
\hline
\end{tabular}




\subsection{Viaje del usuario}

Para el presente proyecto, se ha planteado tres modelos de viaje del usuario para ejemplificar el trayecto que tendrá el usuario por medio de las diferentes plataformas propuestas. Estos tres esquemas representan cómo el usuario inicia, se desenvuelve y se fideliza con el proyecto. Es importante señalar que si bien la etapa de aproximación se desarrolla en una plataforma, esto no impide que el usuario pueda volver y seguir fidelizándose en dicha plataforma. La intención de la creación de 3 modelos de viaje del usuario para este proyecto, es que estos puedan mostrar con mayor claridad los posibles caminos que tomará el usuario para "desplazarse" entre las diferentes plataformas.

Instagram -> YouTube -> Twitter e Instagram

En este modelo del viaje del usuario, la aproximación se da por medio de la plataforma de Instagram. Luego, producto de la publicidad segmentada, el usuario será dirigido a la FanPage de dicha plataforma, donde encontrará el contenido de la plataforma (el cual se detalla al inicio del Capítulo 3). Posteriormente, será redirigido al canal de YouTube, donde se llevará a cabo la fase de consumo del producto; al finalizar cada video se invitará al usuario a visitar la cuenta de Twitter del Sr. Script y, nuevamente, al Instagram del proyecto. En este punto, se iniciará la fase de Fidelización, que incluirá tanto Twitter como Instagram y, en la cual, se desarrollarán acciones para entablar una relación más próxima con el usuario (las cuales se detallan al inicio del Capítulo 3). Luego, en las mismas plataformas, se realizará la fase de mantenimiento para seguir proporcionando de contenido al usuario seguidor, y así mantener su fidelidad con el proyecto.

Aproximación

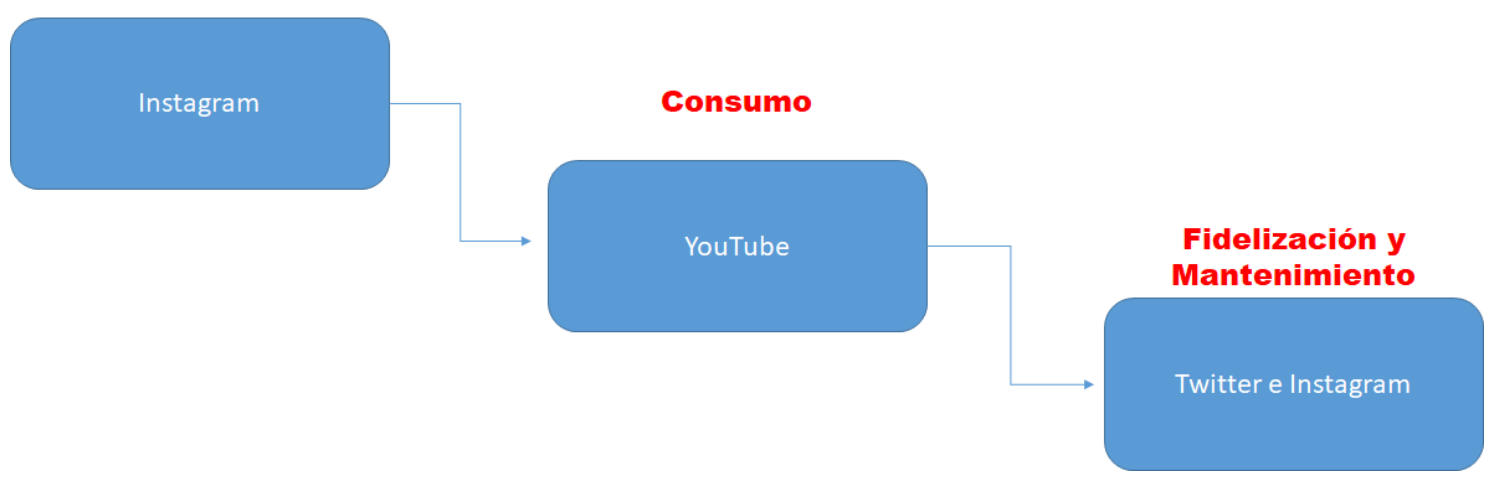

Twitter -> YouTube -> Instagram y Twitter

En este modelo del viaje del usuario, se realiza un proceso similar al anterior, pero con la diferencia de que el usuario empieza su trayecto en la plataforma de Twitter. En este caso, en la fase de aproximación, el usuario empezaría encontrando el perfil del Sr. Script (esto se puede dar 
como recomendación de Twitter, debido a que el usuario sigue cuentas con características similares a la del personaje.). Luego, en el perfil del Sr. Script, el usuario será invitado a ver los videos del canal de YouTube, redirigiéndolo a esta plataforma. En esta, se producirá la fase de consumo, en la cual el usuario consumirá el producto principal (la serie de videos web). Igualmente que en el anterior modelo, al final de los videos se invitará tanto a la plataforma de Twitter como a la de Instagram para la etapa de Fidelización y Mantenimiento. En esta última, se realizarán publicaciones y creación de contenido con el fin de generar una relación más cercana con el usuario, fidelizarlo y mantener la relación creada.

Aproximación

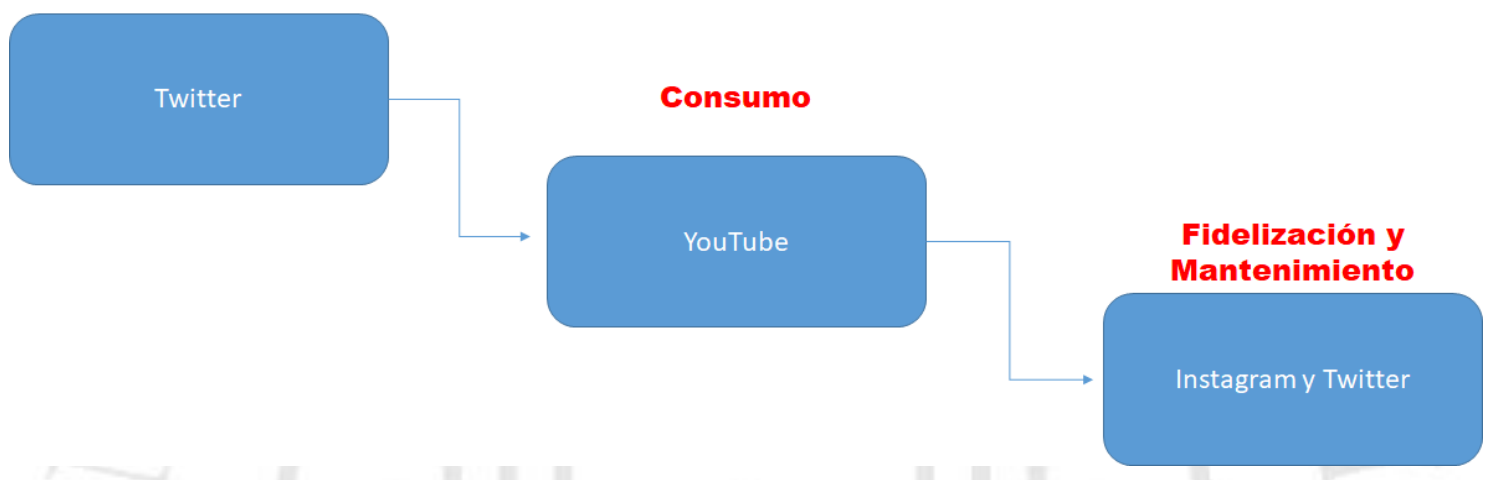

YouTube -> Instagram y/o Twitter

En este modelo del viaje del usuario, el usuario inicia su viaje en la misma plataforma de consumo: YouTube. Este camino se puede dar ya que YouTube le recomienda el canal de Script's Spot al usuario, esto debido a que este sigue canales similares o que producen contenido similar al de Script's Spot. Posteriormente, en los videos, se recomendará visitar las otras plataformas del proyecto, en donde se llevará a cabo la fase de fidelización y mantenimiento, así generando contenido que cree y fortalezca la relación entre el creador de contenido y el nuevo seguidor.

Fidelización y Mantenimiento

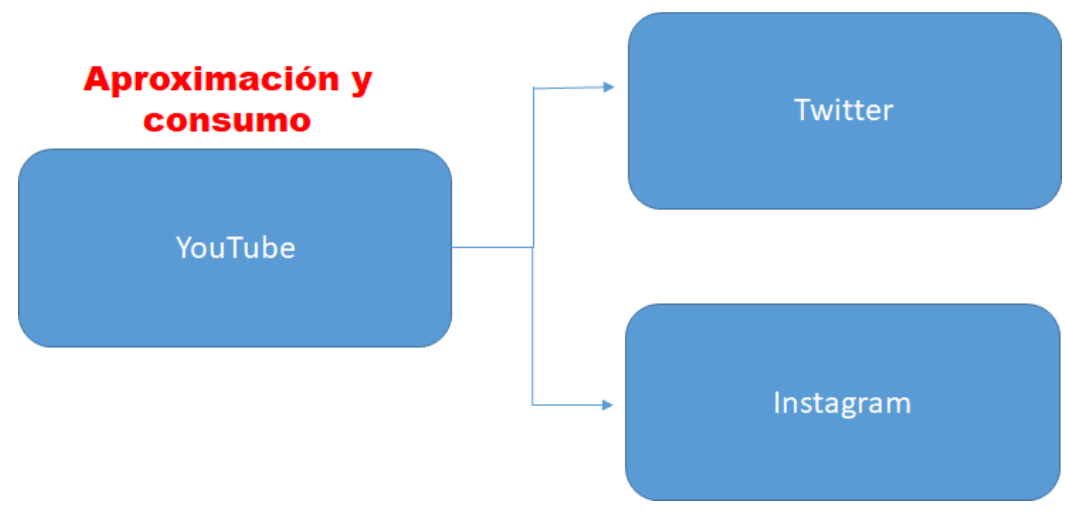




\section{PRÓXIMOS CÁPITULOS DE LA SERIE}

Para que el proyecto esté más organizado y se tenga una idea clara de cómo van a proceder las diferentes etapas de producción de los siguientes capítulos, se han creado las sinopsis de estos; en estos se especifican cómo se irá desarrollando la historia del personaje a lo largo de los capítulos, y las temáticas que se van a ir tratando en cada capítulo.

Cabe destacar que estas sinopsis son referenciales, pues la temática puede varias dependiendo del feedback recibido en las distintas plataformas como se detalló en el Capítulo III "Plan de Difusión y Mantenimiento". De igual manera, de ser necesario, la historia del personaje se irá ajustando a estos cambios de la temática para que haya coherencia y cohesión en el discurso.

\section{- Capítulo 2: La ayuda providencial}

"Sr Script" tiene una oportunidad de salir de la "miseria" en donde vive, tiene una entrevista de trabajo en una productora reconocida de su gusto, todo esto sucedió gracias a que se encontró con un amigo en un bar unas noches atrás. A partir de este suceso, él habla sobre el concepto de "La ayuda providencial", ya que para Sr. Script, su amigo fue eso para él. Al acabar el episodio, pide que le den ánimo para su entrevista y se despide.

- Capítulo 3: Momento "Todo está perdido"

Sr. Script no le fue bien en la entrevista de trabajo y se deprime, él considera que está en un punto muy bajo, así que como temática de este video presenta "El momento 'Todo está perdido'", el cual trata del punto más bajo de un personaje en la trama, donde cree que no va a alcanzar su objetivo. Termina el video con un mensaje medio desesperanzador.

\section{- Capítulo 4: El conflicto}

Sr. Script tiene un problema, sus padres quieren que se vaya de la casa. Esto es un tema complicado para él y que lo ha llevado al conflicto con sus padres. Por eso mismo, en este capítulo, él plantea la temática del "Conflicto" y cómo aplicarlo a una historia de manera correcta, qué funciones cumple y en qué momentos de la trama puede presentarse.

\section{- Capítulo 5: El objetivo del personaje}

Sr. Script tiene que encontrar un nuevo hogar para él, esto plantea una búsqueda que no sólo significará su independencia física, sino también emocional. Con motivo de esto, 
"Sr Script" tratará el tema del "Objetivo del personaje", el cual se divide en objetivo interno y el externo. Esta división, también se aplica a su caso.

\section{- Capítulo 6: Arcos de los personajes}

Sr. Script encontró un departamento nuevo, no el mejor, pero es algo decente. Además, cuenta que ha tenido una reunión de ex-alumnos del colegio y comenta cómo han cambiado algunos de sus antiguos compañeros. Esto lo lleva a reflexionar acerca de los "cambios en los arcos de los personajes" en las películas, siendo ese el tema del que trata el video. Además al terminar, dice que esta reunión le ha hecho recordar sus sueños de juventud y que va a hacer algo al respecto a su situación de inconformidad con respecto a su trabajo y a su vida, en general.

\section{- Capítulo 7: El Clímax}

Sr. Script comenta que ha llegado a un punto de su vida que ha dado un giro de $360^{\circ}$ grados y que ha surgido una oportunidad para que él consiga un trabajo que le guste, deja en suspenso de que se trata y pasa a hablar sobre el tema del capítulo que el "El Clímax" que es el punto más alto o de mayor intensidad de una película (concepto con el cual Sr. Script se identifica en ese momento).

En la parte didáctica, pone ejemplos de qué funciones debe cumplir el clímax para que contribuya a la historia. Terminando el video, anuncia que va a crear su propia productora y que esto contribuirá a que pueda traer más contenido al canal y; a cumplir y vivir de sus sueños en un futuro.

En esta serie, se tiene la intención de que cada capítulo tenga al personaje como hilo conductor, es decir, que no sea necesario ver todos los capítulos para entender la temática ni al personaje; pero, de igual manera, la serie busca recompensar al seguidor que ha visto todos los capítulos con una historia coherente y que genera un sentimiento de "totalizador" al poder completar la historia completa, es decir, una con la cual pueda empatizar, entender y entretenerse. Se hace énfasis en que, el espectador que ve sólo uno o dos episodios, los puede disfrutar de igual manera y sin ningún problema para entender, pero con este proyecto también se quiere premiar al seguidor fiel que ve todos los capítulos.

Cabe resaltar que las temáticas del guión tratadas en el proyecto corresponden, por lo menos en esta primera etapa, al modelo Aristotélico tradicional, sin embargo, se ha planteado temas narrativos de guión fuera de este modelo para un próximo contenido, este último será presentado en un formato determinado, obtenido producto del feedback de los seguidores del proyecto. 


\section{COTIZACIÓN Y MONETIZACIÓN DEL PROYECTO}

En este capítulo, se detallará la cotización con el fin de tomar conocimiento de la inversión en la cual consiste este proyecto y, también pensando a futuro, cotizar cuánto sería el valor de esta serie en el panorama de una posible venta del proyecto o de una coproducción, esto ayudará a tener una mejor idea de lo que habría que cobrar para recuperar la inversión puesta.

Por otro lado, se comentarán las posibles maneras de obtener ganancias con el proyecto, principalmente en YouTube, y hasta qué punto este proyecto podría obtener utilidades en su desarrollo. Un aspecto importante a tomar en cuenta, el cual es importante reiterar, es que esta primera etapa tiene como objetivo crear una comunidad fiel al contenido que el proyecto puede ofrecer, para, en base a eso, buscar maneras de generar ingresos en una siguiente etapa.

Empezando en el aspecto de cotización, se tienen que tomar en cuenta ciertos supuestos para elaborar un presupuesto que dé una mejor idea acerca de la inversión que este proyecto implica.

\subsection{Supuestos:}

- Se supone que tanto la cámara, con la que se graba la parte de videoblog; como la laptop, con la que se editan los videos; se alquilan aparte.

- Se supone que, eventualmente, se contrata a una persona que haga las funciones de asistente de grabación para la parte de videoblog.

- Se supone que se contratan los servicios de un guionista, un editor y un locutor para cada capítulo.

- Se supone que se paga una membresía mensual para el programa Adobe Premiere, en el cual se editan los videos.

- Se supone que se contratan los servicios de Epidemic Sound para los siguientes capítulos y, por lo tanto, se paga la mensualidad del servicio.

- Se supone que se pagará una publicidad en Instagram para la promoción de cada capítulo.

- Se supone que la única compra definitiva del proyecto serán los audífonos y un micrófono condensador que serán incluidos en el presupuesto para recuperar su inversión en un 
plazo de 3 meses.

- Se supone que se realizarán dos capítulos y dos videos de 1 minuto del consejo extra para Instagram, por mes. El proceso de edición incluye a ambos tipos de video (Capítulos y videos del consejo extra de 1 minuto).

- Se supone que la temporada de 7 capítulos y, las publicaciones de mini videos de 1 minuto dando un consejo extra, se completan en 4 meses.

Con estos supuestos $\mathrm{y}$; recolectando precios y costos referenciales se arma el siguiente presupuesto por capítulo:

\subsection{Presupuestos:}

\begin{tabular}{|l|r|}
\hline \multicolumn{2}{|c|}{ Presupuesto por capítulo } \\
\hline Ítem & Costo en nuevos soles \\
\hline Alquiler de la laptop & S/. 400 \\
\hline Alquiler de la cámara & S/. 160 \\
\hline Sueldo del editor & S/. 480 \\
\hline Sueldo del asistente de grabación & S/. 80 \\
\hline Sueldo del guionista & S/. 80 \\
\hline Sueldo del locutor & S/. 80 \\
\hline Mitad de la mensualidad de membresía de adobe Premiere & S/. 36 \\
\hline Mitad de membresía de Epidemic sound & S/. 26 \\
\hline Publicidad de post de Instagram & S/. 64 \\
\hline Costo a pagar por los audífonos por episodio & S \\
\hline Costo a pagar por el micrófono por episodio & S3 \\
\hline TOTAL & \\
\hline
\end{tabular}

Y recordando el supuesto de que la serie se completa en 4 meses, por la temporada se obtiene el siguiente presupuesto: 


\begin{tabular}{|l|r|}
\hline \multicolumn{2}{|c|}{ Presupuesto por temporada } \\
\hline Ítem & Costo en nuevos soles \\
\hline Alquiler de la laptop & S/. 2800 \\
\hline Alquiler de la cámara & S/. 1120 \\
\hline Sueldo del editor & S/. 3360 \\
\hline Sueldo del asistente de grabación & S/. 560 \\
\hline Sueldo del guionista & S/. 560 \\
\hline Sueldo del locutor & S/. 252 \\
\hline Mensualidad de membresía de adobe Premiere & S/. 182 \\
\hline Membresía de Epidemic sound & S/. 448 \\
\hline Publicidad de post de Instagram & S/. 60 \\
\hline Costo a pagar por los audífonos en la temporada & S/. 102 \\
\hline Costo a pagar por el micrófono en la temporada & S/. 10004 \\
\hline TOTAL & \\
\hline
\end{tabular}

Con este presupuesto, se puede tener una idea más clara acerca del valor de la inversión del proyecto, y sirve como referente para ver en un futuro cómo se desarrolla el proyecto en cuanto a retorno de la inversión puesta. Además, sirve como una guía para el futuro, ante un posible panorama de venta del proyecto o coproducción de este.

Por otro lado, analizando la manera en cómo se trabaja en YouTube y el contexto en el que los creadores de contenido o Youtubers se desarrollan, se pueden identificar 3 maneras de obtener ingresos con la plataforma de YouTube:

- La primera manera es el CPM (Costo por cada mil vistas), el cual se encuentra en la plataforma de YouTube y consiste en que ciertas empresas buscan anunciar sus productos en las redes sociales y le pagan a YouTube para promocionarlos; YouTube como plataforma selecciona ciertos videos, en donde pone los anuncios de estas marcas y como beneficio para el canal, en donde se pone el video, el creador de contenido de dicho canal recibe un porcentaje de las ganancias. Se llama "Costo por cada mil vistas" porque empieza a generarse ingresos a partir de las mil vistas del anuncio en el video. En este panorama, aparecen los denominados "Partners" que son empresas que entablan una 
relación profesional con el creador de contenido, por medio de YouTube, para poner publicidad especifica en ciertos videos que sean de su interés.

Este medio es uno muy usado por varios creadores de contenido, pero existe un problema con los derechos de autor que puede ser perjudicial para las intenciones para generar ingresos del proyecto. Sin embargo, este problema se tratará de evitar con el procedimiento explicado en el Capítulo IV de "Plan de Difusión y Mantenimiento", en donde, por medio de un canal secundario se realizarán pruebas de publicación para evitar que YouTube censure o desmonetice un video.

- La segunda manera es contactar con las marcas directamente, para promocionar de manera directa ciertos productos o servicios que estas puedan estar ofreciendo. Estos acuerdos, suelen darse entre canales y empresas que comparten la misma temática o que hablan sobre el mismo rubro. En esta modalidad, es mucho más sencillo llegar a acuerdos con independencia del aspecto de los derechos de autor, así que es una vía más segura para intentar generar ingresos en este proyecto. Estas empresas, muchas veces, asumen el papel de sponsors o patrocinadores del canal, quienes reciben promoción de su producto $\mathrm{y}$, a cambio, sostienen económicamente al canal de YouTube.

- Por último, se encuentra la modalidad de ofrecer productos y/o servicios propios a través de los mismos videos; esto también sería más efectivo ya que se realiza sin intermediarios, ya que dependería de un precio fijo, producto del acuerdo de dos partes que buscan un beneficio. En el caso de este proyecto, podrían ofrecerse servicios de asesoría o de realización y escritura de guión, según como se vaya realizando este proyecto.

Como ya se mencionó, en esta primera etapa, el objetivo es generar una comunidad fieles de seguidores que apoyen los contenidos y den feedback sobre lo que se realiza en este proyecto. A raíz de este feedback, se puede generar nuevos tipos de contenido que no tengan problemas con el aspecto de los derechos de autor; y que posteriormente, en una siguiente etapa del proyecto, genere un ingreso de una manera más fácil por medio del CPM, así complementando lo que se va realizando desde esta primera etapa. 


\section{LOGROS Y RESULTADOS}

Para este capítulo, se entrevistó a 5 diferentes profesores para recabar opiniones y corroborar que aspectos del proyecto funcionaban y cuáles se podía mejorar. Entre los entrevistados estuvieron los profesores: César Loli, Álvaro Iparraguirre, Juan Carlos Vela, Julio Wissar y Eduardo Ojeda. Asimismo, se realizó un focus group con 18 personas del Círculo de Cine de la Universidad de Lima para recolectar impresiones sobre el producto, además de analizar y determinar qué elementos del producto se pueden cambiar para la mejora de este.

En este capítulo, primero se detallará que dijo cada entrevistado y lo que se precisó en el focus group, luego se plantearán conclusiones en donde se detallará lo que se tomará en cuenta y lo que no, y se explicaran las razones de esto.

\section{$\underline{6.1 \text { Entrevistas }}$}

\section{Profesor Loli}

En primer lugar, se conversó con el profesor César Loli, se le explicó en qué consistía el proyecto y se le mostró el video. Después de verlo, él comentó que el estilo y contenido eran de su agrado, además mencionó que la estructura del video estaba bien planteada. Asimismo, mencionó que, viendo el video, se entendía el público objetivo al que iba dirigido, esto se lograba por medio de la personalidad del personaje y los ejemplos que pone en el video.

Por otro lado, el profesor Loli recomendó disminuir el uso de la pantalla en negro (sobre todo en las partes del Storytelling, donde se cuenta parte de la historia del personaje).ya que podía, desde su punto de vista, ser contraproducente como producto de consumo en Internet debido al dinamismo de este y a que un consumidor promedio podría "aburrirse" rápidamente, si es que no ve algo que lo atrapa en los primeros segundos de un producto audiovisual. Con excepción de este punto, en un balance general, el profesor considera que el proyecto es una buena propuesta que puede llegar a un público determinado de comunicadores o aficionados al cine, sin mayor problema.

\section{Profesor Iparraguirre}

En segundo lugar, se tuvo una reunión con el profesor Álvaro Iparraguirre, quien consideró que la primera parte del storytelling se podía reducir en duración, ya que él consideraba que era muy excesivo el tiempo dado a este (1 minuto y medio aproximadamente) y recomendaba reducirlo a unos 30 segundos como máximo. Por otro lado, destacó que la mayor virtud del proyecto es el conocimiento acerca de las temáticas de guión que se presenta en el proyecto. Asimismo, 
recomendó reducir el tiempo de video a 5 o 6 minutos ya que sería un contenido más "digerible" para el público. Además, también destacó la personalidad del personaje como algo positivo, pero que él consideraba que podría ser un poco mayor al que se presenta, es decir, en vez de presentar a un guionista de 25 años, que se presente uno de 30 o 32 años, con mayores responsabilidades y con "más peso encima" que sirven como detonante para que él inicie este proyecto.

En el aspecto de contenido, el profesor recomendó incluir un personaje "extra" para tener mayor dinamismo, este personaje se caracterizaría por ser más crítico que el narrador y contraponer a su figura, lo cual haría que la percepción del narrador sea más agradable con respecto a este nuevo personaje presentado, además él consideró que esto puede generar mayor diversidad de contenido en el storytelling en los futuros capítulos y evitar que sea repetitivo. Adicionalmente, en el aspecto de presentación de ejemplos recomendó que el personaje de opción al espectador para que este decida qué películas son buenas o no, en vez de plantearlo desde un punto de vista subjetivo, el cual puede no ser del agrado de parte de la audiencia. Además, destacó que el ritmo y los "gags" (recursos graciosos) usados le parecían oportunos y que funcionaban bien. Destacó que el lenguaje y ejemplos usados son de un entendimiento muy amplio, lo cual permite que llegue a una mayor cantidad de público.

Además, resaltó que hay una variedad bien amplia de temáticas para hablar, ya que incluye tanto guión como cine, en general; y esto permite que la exista una gran posibilidad de crear varios otros capítulos o diversificar en otro tipo de contenido en relación a la temática principal. También, recalcó que el uso de espacios físicos puede caracterizar bien al personaje, como ejemplo de esto, pusó a los "Cinéfilos", y que considere añadir ese agregado al proyecto, ya sea en los capítulos o en las otras redes sociales. Asimismo, consideró que el uso de los memes como recurso está bien planteado y que puede empatizar con la gente debido a su contemporaneidad. Por otro lado, el profesor Iparraguirre recomendó trabajar más en el perfil del personaje, ya que así se encontrará un estilo más definido cuando este tiene que expresarse en los vídeos o en diferentes plataformas. Por último, él considera que el uso de plataformas como Instagram o Twitter pueden ayudar en la creación del personaje con respecto al público y puede contribuir generando más contenido para el espectador y complementar los capítulos.

\section{Profesor Vela}

En el caso del profesor Vela, él destacó que el contenido de la parte del discurso didáctico le parece muy bien estructurada, clara y con ejemplos bien interesantes, los cuales se presentan con un estilo atractivo. También, destaca que el estilo y tono del narrador encaja muy bien en el discurso, sin embargo, él considera que la primera parte de storytelling, donde se cuenta la vida del personaje, es algo extensa y que el ritmo va muy lento y "triste", en contraposición con la 
parte didáctica, en consecuencia, recomienda emparejar el ritmo (tanto del tono de la narración como el ritmo de este) para que la presentación del producto sea más uniforme y pueda “enganchar" desde el inicio.

Además, con relación al proyecto, mencionó que le parece interesante que las personas puedan conocer al personaje a través de diferentes plataformas, ya que considera que el narrador es interesante y puede ser de interés para el público. También, destacó que la ironía del personaje y la capacidad de "reírse de sí mismo" es un gran acierto que genera simpatía por el personaje y que esa característica debería continuar en siguientes capítulos. Además, resaltó que las pantallas en negras que son extensas pueden llegar a ser un riesgo para el primer capítulo ya que puede desentonar con el ritmo propuesto en la segunda parte del vídeo.

\section{Profesor Wissar}

También, se entrevistó al profesor Wissar, quien mencionó que el aspecto de la edición se podía mejorar, asimismo, mencionó que las pantallas en negro eran un buen recurso, pero que el uso de este era excesivo en algunos momentos y su duración era muy larga. De igual manera, comentó que la voz en off funcionaba por momentos, pero que cuando aparecía esta voz con el fondo negro no funcionaba de igual manera, y esto podría cansar al espectador. También, destacó que el uso de un personaje crítico y humorístico con un fin didáctico le parecía interesante y podría ser diferencial. Además, recomendó definir bien los referentes en el aspecto de edición, ya que al tratarse de una comedia un buen referente puede ayudar a cumplir el objetivo de entretenimiento. Asimismo, recomendó revisar la parte acústica del video, ya que había unos "desniveles" de sonido que se tenían que ajustar. El profesor, también recomendó que el video piloto debería durar 10 minutos con el fin de que sea un video apto para utilizar la opción de monetización en la plataforma de YouTube.

Además, recomendó determinar la temática de los siguientes capítulos y cómo se llevarán a cabo para tener una mejor idea del proyecto. También, reconoció que la elección del tema del primer capítulo: "La imagen de apertura" es uno bien elegido ya que es un tema que no muchos toman en cuenta, pese a ser considerado "básico", y recomienda que los siguientes capítulos de la serie sigan esa línea de temática ya que puede ser de interés del público. En el aspecto de temática (el guión y el cine), el profesor reconoció que los referentes tomados como "Te lo resumo así nomás" y "Top cómics" son muy buenos, ya que refieren a referentes internacionales y que se puede asociar bien en la comunidad hispanohablante de YouTube que ve este tipo de contenido. Además, recomendó incluir producciones audiovisuales de habla hispana en los videos, dado que el contexto donde se va a desarrollar el proyecto permitiría que se hablen de este tipo de películas 
o producciones en los siguientes capítulos, y así tenga una relación más directa con el público espectador.

Asimismo, recomendó tener un colchón de capítulos antes de iniciar el proyecto, para así asegurar continuidad. Además, recomendó crear una parrilla de contenidos con los primeros episodios y los diferentes tipos de contenidos que se publicarán la primera fase del proyecto. En cuanto al inicio del video, recomendó que, si bien la historia estaba bien, el ritmo se podía acelerar y volvió a recomendar a "parchar" algunos momentos de pantalla en negro para evitar que el espectador pierda el interés por el video. También, recomendó usar los subtítulos de los videos de YouTube ya que algunas palabras pueden funcionar como "etiquetas" que ayuden a los espectadores a encontrar el contenido del canal de manera más fácil. Asimismo, recomendó el uso de fotogramas o fotos en lugar de videos (en lugar de los videos más largos) para evitar tener problemas con el copyright en la plataforma de YouTube.

\section{Profesor Ojeda}

Propuso incluir, de una manera más pronunciada, la historia del personaje en el relato con el fin de generar más empatía con el espectador; también recomendó evitar algunos calificativos negativos por parte del personaje ya que esto puede desalentar al público de continuar viendo el contenido del video, y además recomendó evitar las "lisuras", pues pensando a futuro podría ser un problema en la búsqueda de sponsors o colaboraciones. Asimismo, sugirió que los consejos que se van dando en el video, se vayan mostrando visualmente para que sea un contenido más atractivo para el espectador y ayude en la retención de conocimientos que se quiere lograr.

Por otro lado, reconoció que el estilo y el ritmo del contenido están bien definidos; y añadió que el video cumple con el fin didáctico y de entretenimiento. Además, mencionó que la estructura del video es marcada y contribuye muy bien al propósito de este. En adición, se le consultó por el plan de medios del proyecto y él comentó que es uno muy bien planteado; sin embargo, de igual manera recomienda que en un futuro se cree una FanPage en la plataforma de Facebook con el fin de tener un acercamiento más próximo con posibles empresas que pueden funcionar como sponsors o patrocinadores del proyecto.

\subsection{Focus group}

En el focus group realizado se contó con la asistencia de 18 personas pertenecientes en su gran mayoría al Círculo de Cine de la Universidad de Lima, un grupo que se encuentra en uno de los públicos objetivos del proyecto, lo cual lo hace una buena referencia a quien pedir feedback acerca de este proyecto. Entre las principales impresiones están los siguientes: 
Se destacó que los títulos usados ayudaban a la mejor retención de lo enseñado, por lo tanto aportan al fin didáctico. Asimismo, consideran que el contenido es digerible y entendible para un público masivo, ya que se usan términos que pueden ser comprendidos sin mayor problema por los espectadores. Por otro lado, recomendaron que las pantallas en negro, con los diálogos en los que se usa el filtro de voz, fueran más pausadas para que se pueda entender mejor el comentario sarcástico en el discurso. También, se sugirió agregar imágenes o fotogramas de los guiones de las películas que se va narrando, para que así el video sea más interactivo.

Asimismo, se recomendó corregir los niveles de audio en algunas partes del video para que se pueda escuchar sin problemas en cualquier dispositivo. Además, consideraron que sería buena idea colocar música de fondo para que sea un producto más digerible para algunos espectadores. En adición, se destacó que el contenido era muy interactivo y didáctico y que, por consecuencia, llega a cumplir su función. Destacaron que si bien se puede acortar la primera parte, esta establece varios gags y recursos que se usarán en la posterior parte del vídeo, así generando un código audiovisual entre el video y los espectadores. Un punto a rescatar es el gusto por "la burla a uno mismo" que mostraba el personaje, ya que eso generó simpatía en los miembros del focus. Finalmente, resaltaron que la parte de storytelling cuenta con una historia y con un personaje interesante, con el cual el público objetivo puede lograr empatizar.

\subsection{Conclusiones}

Tras el análisis de las entrevistas y el focus group, se tomaron los siguientes puntos en cuenta para el proyecto:

\subsubsection{Con respecto al capítulo piloto:}

- Se realizará la inclusión de imágenes en los espacios muy prolongados de pantalla negra, esto se realizará ya que es una sugerencia recurrente y que puede ser aprovechada como una oportunidad para incluir una mayor cantidad de gags como los memes y apelar a una respuesta de simpatía por parte de los espectadores.

- También se corregirá aspectos técnicos como aspectos de sonido y algunos detalles en el ritmo del video con el fin de brindar el mejor producto audiovisual posible y que el espectador tenga la mejor experiencia posible con el video.

- Se buscará darle tiempo a los comentarios sarcásticos que poseen el filtro de voz, con el fin de que estos sean más claros y generen simpatía en el espectador, esto también está 
incluido en la revisión en el aspecto de sonido, pero es un punto importante a resaltar

- Se cambiará la orientación de la imagen y se agregarán textos que modifiquen los extractos de películas que duren más de 10 segundos, para así evitar problemas de copyright.

\subsubsection{Con respecto a futuros capítulos}

- Se tomará en cuenta la sugerencia sobre utilizar referentes hispanohablantes en los videos, ya que el usar ejemplos acerca de producciones de habla hispana puede generar una mayor cercanía y empatía con el espectador. Un referente parecido que utiliza este recurso es el canal de YouTube "Te lo resumo", quien utiliza estas producciones hispanohablantes con fines de entretenimiento y de hacer comedia.

- Asimismo, se tendrá en consideración el acortar la parte de storytelling, incluso esta parte no siempre se presentará al inicio del capítulo, esto con el fin de atraer de una manera más inmediata al espectador. Sin embargo, la parte del storytelling del capítulo piloto no sufrirá mayores cambios, ya que su extensión y ritmo desacelerado se entiende tanto como una presentación del personaje (con el cual se interactúa por primera vez, por lo que necesita tiempo para familiarizarse) y también se entiende como una presentación de los diferentes gags y/o recursos que se utilizarán a lo largo del video.

- Se evaluará posibilidad de usar fotogramas en algunas partes del video para evitar problemas de copyright, esto dependerá de la respuesta del público con respecto al formato actual del proyecto, y con el desenvolvimiento del proyecto en YouTube con respecto al aspecto del copyright

- También, se considerará añadir a un personaje extra, aunque es algo complicado ya que, si bien tiene un fin narrativo interesante, esto puede significar el incremento del presupuesto, esto se traduciría como un sueldo más (si se contrata a otro narrador) o como trabajo extra del narrador de turno, lo que conllevaría a que se extienda su horario de trabajo, lo cual se traduciría en un mayor pago para él.

- Se considerará la implementación del música de fondo para los siguientes videos, por eso se tiene pensado una próxima incorporación al programa de "Epidemic Sound", con el cual se pagaría una mensualidad para usar la música que ellos ofrecen. Esto no se aplica en el video piloto, ya que se quiere ver la respuesta del público al actual formato y después, analizar si es necesario la inclusión de esta música; pero, de igual manera, se 
tiene en cuenta para futuros videos.

- Se evaluará introducir más la historia del personaje en el relato de los videos, siempre y cuando éste no tome mayor protagonismo que la dinámica de enseñanza acerca de los conceptos que se quieren transmitir. Esto también dependerá de la respuesta del público hacia el producto.

- Se evaluará la posibilidad de reducir algunos comentarios fuera de tono como las lisuras, dependiendo de cómo se vaya desarrollando el proyecto y de cuál es la respuesta del público ante este cambio.

- Asimismo, se evaluará agregar algunos recursos visuales que colaboren con la retención de conocimientos. Estos recursos serían complementarios a la voz en off que narra las funciones de la imagen de apertura en el video. Uno de estos recursos podría ser imágenes o fotogramas de guiones de las películas que se van narrando.

\section{$\underline{6.3 .3 \text { Con respecto al proyecto }}$}

- Se tendrá en cuenta el aspecto de la monetización y de llegar a 10 minutos en cada video (siempre y cuando se planee desde el proceso de pre-producción), pero en esta primera temporada, si bien se busca generar algún ingreso, el principal objetivo de esta temporada es fidelizar a un público determinado, con el fin de luego generar tipos de contenido (además de esta serie de videos didácticos) de los cuales también se pueda monetizar.

- Un aspecto importante a tener en cuenta, es preparar varios capítulos antes del estreno del primero, para así tener material suficiente para trabajar de manera más ordenada a medida que avanza el proyecto; esto ayudará a evitar retrasos en la publicación de los capítulos.

- También, se toma en cuenta la creación de una parrilla de contenidos, para así tener una mejor planificación de los contenidos que se van a subir en las diferentes plataformas. Para este proyecto, se adjunta una parrilla que incluye la planificación de los 4 primeros capítulos de la serie.

- También, se tomará en cuenta la sugerencia de incluir espacios físicos del personaje, a través de Instagram o Twitter; esto con el fin de dar a conocer al personaje al público. A medida que avanza el proyecto, se irá evaluando qué espacios y/o aspectos de la vida del personaje se van mostrando visualmente en las redes sociales, con el fin de generar mayor 
cercanía con el espectador.

- Se tomará en cuenta la creación de una FanPage de Facebook en una siguiente etapa, esto con el fin de contactar con diferentes empresas con las cuales se puedan establecer relaciones de sponsor o de patrocinio.

- Se tomará en cuenta la utilización de los subtítulos para la fácil identificación en la plataforma acerca de los temas tratados en los capítulos. Esto se tiene que evaluar ya que puede ser un facilitador para que personas contratadas por algunas productoras encuentren el video y busquen eliminarlo de la plataforma. 


\section{LECCIONES APRENDIDAS}

El proceso se realizó en varias etapas que presentaron diferentes retos, los cuales dejaron alguna lección o aprendizaje que sirvió para continuar con el proyecto de manera exitosa o que servirán para futuros proyectos personales.

En primer lugar, hablando en términos generales, el proceso de edición fue bastante complicado ya que se manejaron más de 100 archivos de audio y varios videos recolectados de internet. Esto, obviamente, tomó bastante tiempo en recolectar, pero luego al momento de editar el video se complicó más, pues al no haber organizado y distribuido bien los audios por nombres específicos o agrupado por folders con nombres que indicarán a qué parte del discurso pertenecía el audio, el proceso demoraba más de lo que debía. Así que, una enseñanza básica pero importante es saber organizarse cuando uno edita, esto se puede realizar de cualquier manera que uno considere conveniente. Hago mención de este aprendizaje, aunque suene básico, porque muchos no lo ponen en práctica (como yo) y demoran el proceso de realización y entrega de ciertos trabajos: En esta instancia universitaria, las consecuencias no son tan grandes, pero en el ámbito profesional y, sobretodo, cuando otros dependen de nuestro trabajo, este aprendizaje o lección aprendida es importante para tomar en cuenta y aplicarlo a nuestro trabajo.

Por otro lado, este proyecto estaba pensado para pertenecer al canal de YouTube de "Desvío Producciones", ya que, quien escribe, pertenecía a esta productora; pero en un punto por motivos personales y de trabajo, decidí retirarme de esta. A pesar de ello, mi intención fue continuar con el proyecto para el canal de Desvío, pero considerándome como un realizador externo, y a "Desvío Producciones", como un cliente. Esto se intentó llevar a cabo, pero no se logró concretar por falta de interés y organización por parte de "Desvío Producciones" hacia el proyecto. Por ese motivo, decidí realizar el proyecto de manera independiente de esta productora; lo cual me ha traído muy buenos resultados ya que he podido tener libertad creativa al momento de realizar mi propuesta, asimismo, he podido trabajar a un ritmo más acorde a los tiempos que manejo, y sin duda, ha quedado un producto que me satisface a mí como realizador y gestor de este proyecto. Por lo tanto, el aprendizaje que obtengo de esta experiencia es que para proyectos personales, en los cuales uno esté en las facultades y tenga la posibilidad de realizarlo solo, es mejor que lo haga sin depender de terceros, ya que existe la posibilidad de que estos no tomen el proyecto con la misma seriedad que uno le pone. Además que ayuda a que el flujo de trabajo sea más personalizado y adecuado a los tiempos propios de uno, así brindando una facilidad mayor a la hora de trabajar. 
Otro aprendizaje importante es el de planificar bien un proyecto y tomar en consideración todas las acciones a realizar, para así no desestimar algunas tareas que le dará mucho peso a tu proyecto. Por ejemplo, al inicio del curso Trabajo Profesional II, se planeaba hacer 5 videos pensando que se podían realizar sistemáticamente y omitiendo varios pasos intermedios. Cuando se decidió añadir al personaje narrador al proyecto, la meta bajó a 2 o 3 videos. Pero, a medida que fue avanzando el semestre, me di cuenta de que el proceso de creación de personaje, encontrar el estilo y tono adecuado, la escritura del guión, las pruebas de locución y; propuestas acústicas y visuales eran muy importantes. Esto, obviamente, tomó mucho tiempo y era un proceso que no se podía apurar, sino que tenía que surgir de una manera calmada, organizada y bien pensada. Esto ayudó a que el proyecto tenga coherencia en su propuesta general y, definitivamente, ayudó a tener un mejor producto final que va de acorde con los objetivos a alcanzar. Por eso, considero que una lección importante de este proceso es la correcta planificación y evaluar la importancia de cada tarea y cómo esta puede contribuir a los objetivos del proyecto.

Por otro lado; una lección, más específica en el tema de la edición de video o creación de contenido audiovisual, es intentar cosas nuevas en la sala de edición que refuerce su intención en el discurso. Por ejemplo, en la edición de la parte visual del video, cuando estaba revisando algunos clips de la sección especial de Adam Sandler, me encontré con un video en donde un personaje golpea varias veces al personaje de Adam Sandler con un palo (Sandler \& Dugan, Extracto de la película "No te metas con Zohan", 2008), esto me dió la idea de utilizar el recurso de los memes en el vídeo para cambiar esa situación extraña por un graciosa, al poner el texto "Yo" en quien tenía el palo, y "El mero Adam Sandler" en su personaje; esto reforzaba la intención del discurso propuesto e iba acorde con lo que se estaba contando acerca del actor. Este recurso fue fruto de un proceso creativo espontáneo, el cual permitió usar esta idea de los memes en otras partes del video y, así cumplir de mejor manera el objetivo de entretener al espectador. El aprendizaje de esto es intentar plasmar ideas propias en el video, las cuales pueden aparecer en el proceso de edición porque puede resultar en una muy buena idea que ayude a reforzar el objetivo del discurso. Pese a que puede involucrar mucho tiempo de trabajo en la edición (el hacer cada meme demoraba entre 30 a 40 minutos de trabajo), puede ser una idea que sea de mucha utilidad para el producto final.

Por último, en la última etapa de la realización de este proyecto, la cual consistió en la realización de entrevistas y focus group para la validación del proyecto, se aprendió a ponderar las diferentes subjetividades y evaluar de la mejor manera, cuales pueden contribuir al proyecto, tanto de manera inmediata como para los próximos capítulos. Esto contribuyó y le hizo mucho bien al proyecto, ya que ha permitido sentar una base más sólida para el futuro de este. 
Como conclusión, se puede decir que en el proceso de realización de este proyecto se presentaron dificultades y experiencias que dejaron aprendizajes útiles que se pueden aplicar en mi vida personal, académica y profesional para diferentes tipos de proyectos, esto ayudará a mejorar el flujo de trabajo y obtener mejores resultados a futuro.

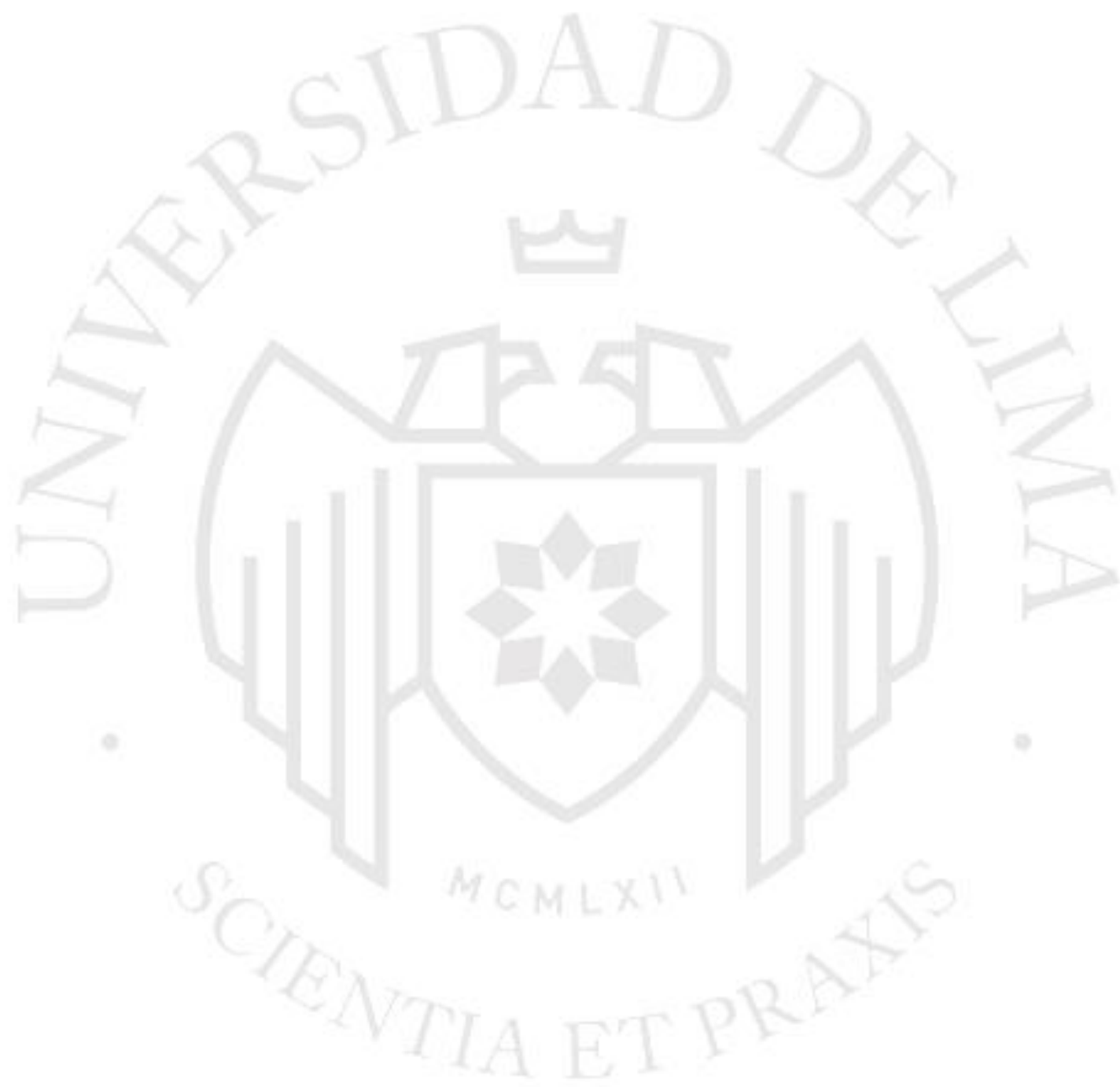




\section{REFERENCIAS}

- Arias, R. D. (2006). Evolución de la comunicación audiovisual: de la televisión clásica al videoblog. In Congreso Internacional de Blogs y Periodismo en la Red, Madrid. Fragua. http://eprints. ucm. es/5983/ (revisado 02-06-12).

- Cohen, J. (2001). Defining identification: A theoretical look at the identification of audiences with media characters. Mass communication \& society, 4(3), 245-264.

- Garcés Pérez, C. J., \& Vera Miranda, J. M. (2019). Análisis comparativo sobre el consumo de producción audiovisual nacional e internacional en Youtube de los niños de 8 a 11 años de edad en la ciudad de Milagro (Bachelor's thesis).

- Garrido Herrera, J. B. (2015). Importancia del proceso creativo en la construcción de un guión para la puesta en escena a partir de una bitácora de trabajo (Bachelor's thesis, Quito: UCE).

- Grandío, M. D. M. (2009). El entretenimiento televisivo. Un estudio de audiencia desde la noción de gusto.

- Labastida i Juan, I., \& Iglesias Rebollo, C. (2006). Guía sobre gestión de derechos de autor y acceso abierto en bibliotecas, servicios de documentación y archivos.

- Merleau-Ponty, M. (2003). El mundo de la percepción. Siete conferencias.

- Muñoz Villar, C. (2014).El meme como evolución de los medios de expresión social. Disponible en http://repositorio.uchile.cl/handle/2250/129749

- Ramos, L. M., \& Flores, T. G. (2014). El vídeo como recurso didáctico para reforzar el conocimiento. Memorias del Encuentro Internacional de Educación a Distancia, (3).

- Rosales Statkus, S. E., \& Roig-Vila, R. (2017). El relato digital (digital storytelling) como elemento narrativo en el ámbito educativo.

- Sandler, A. (productor) y Dugan, D. (director). (2008). No te metas con Zohan.[Cinta cinematográfica] E.U.: Happy Madison 
- Te lo resumo. (2018, 3 mayo). Sin Fumar | Crítica a Avengers Infinity War (Hasta las manos de spoilers) [Archivo de vídeo]. Recuperado de https://www.youtube.com/watch?v=y4V9WsqsK6w

- YouTube. (s.f.). Derechos de autor| Uso legítimo - YouTube. Recuperado 16 febrero, 2020, de https://www.youtube.com/intl/es-419/about/copyright/fair-use/

- YouTube. (s.f.-b) ¿Cómo funciona el Content ID? - Ayuda de YouTube. Recuperado 16 febrero, 2020, de https://support.google.com/youtube/answer/2797370?hl=es 